\section{Željko Brguljan}

samostalni istraživač / independent researcher

M. Deanovića 11, Zagreb

bergulian@gmail.com

Prethodno priopćenje / Preliminary communication

UDK / UDC: 75 Stroj, M.

13. 11. 2015.

\title{
Prijedlog za prilog djelu Mihaela Stroja
}

Ključne riječi: Mihael Stroj, bidermajer portret, Carolina Mazzalors-Hassmann Keywords: Mihael Stroj, Biedermeier portrait, Carolina Mazzalors-Hassmann

Dosad nepoznatu sliku »Portret Caroline Mazzalors-Hassmann«, nedavno doniranu Pomorskom muzeju Crne Gore u Kotoru, datirali smo oko godine 1840., a ukupnost dojma i pomna raščlamba, unatoč elementima koji mogu upućivati i na druge autore, navode nas na prijedlog atribucije ovog djela slovenskom slikaru Mihaelu Stroju. Ovaj tako jedinstven rad koji zrači ljepotom $i$ začudnošću, smatramo da je naslikan upravo prepoznatljivom elegantnom manirom ovog autora.

U listu Hrvatski glasnik (veljača 2015.), mjesečnika Hrvatskoga građanskog društva Crne Gore - Kotor, objavljen je članak o donaciji gospođe Nade Radimir Pomorskom muzeju Crne Gore u Kotoru. ${ }^{1}$ Nada Radimir, izdanak starih bokeljskih rodova Perasta (Smeća) i Dobrote (Radoničić, Radimir) nakon rodnog Sarajeva, živjela je u Beogradu, Zagrebu, New Yorku i Ženevi te se na kraju nastanila u Australiji. Unatoč čestim seljenjima, velikim trudom i brigom uspjela je sačuvati vrijedno obiteljsko naslijeđe posljednjih potomaka grofovske obitelji Smeća (Smecchia), ${ }^{2}$ koje čine obiteljski portreti, stilski namještaj, predmeti umjetničkog obrta i rijetki primjerci knjiga, te ga vratiti u Boku kotorsku - zavičaj svojih predaka, doniravši tu »lutajuću « obiteljsku zbirku kotorskom muzeju.

Među nekoliko, u spomenutom članku, reproduciranih portreta istaknutih članova peraške obitelji Smeća, posebno nas se dojmio i učinio nam se poznatim lijepi portret dame $\mathrm{u}$ stilu bidermajera, naveden kao "portret kontese Karoline Hasman«, darodavkine praprabake. O portretiranoj Carolini Hassmann malo što znamo. Nepoznato nam je mjesto, što- više i zemlja, njezina rođenja, a upitna je i njezina grofovska titula. ${ }^{3}$ Iako je, kako ćemo poslije iznijeti, pretpostavljeni autor $\mathrm{u}$ vrijeme nastanka njezina portreta boravio $\mathrm{u} \mathrm{Hr}$ vatskoj, a potom u Sloveniji, nema osnova za zaključak da je obitelj Hassmann živjela u ovim zemljama. Ne našavši niti jedan zapis ovog prezimena, kao i njegovih inačica (Hasmann, Hassman, Hasman) u temeljitim pretragama brojnih izvora obiteljskih prezimena kako u Hrvatskoj tako i u Sloveniji, možemo pretpostaviti kako obitelj portretirane dame nije obitavala na našim područjima. ${ }^{4} \mathrm{U}$ doba kad je portretirana rođena i nešto ranije, krajem 18. i na početku 19. stoljeća, prezime Hassmann nalazimo u Njemačkoj ali i u Austriji. ${ }^{5}$ Zanimljiv je podatak o obitelji Johana Hermana Hassmanna koja je tada prebivala u Lienenu, ${ }^{6}$ tadašnjoj kraljevini Pruskoj koju je pretpostavljeni autor portreta Caroline Hassmann vjerojatno posjetio i to upravo u vrijeme nastanka slike. Na možebitni zavičaj portretirane dame upućuje i velik broj osoba prezimena Hassmann koje su u spomenutom razdoblju upravo iz njemačkih zemalja imigrirale u Ameriku, a znakovito je da je među njima i 


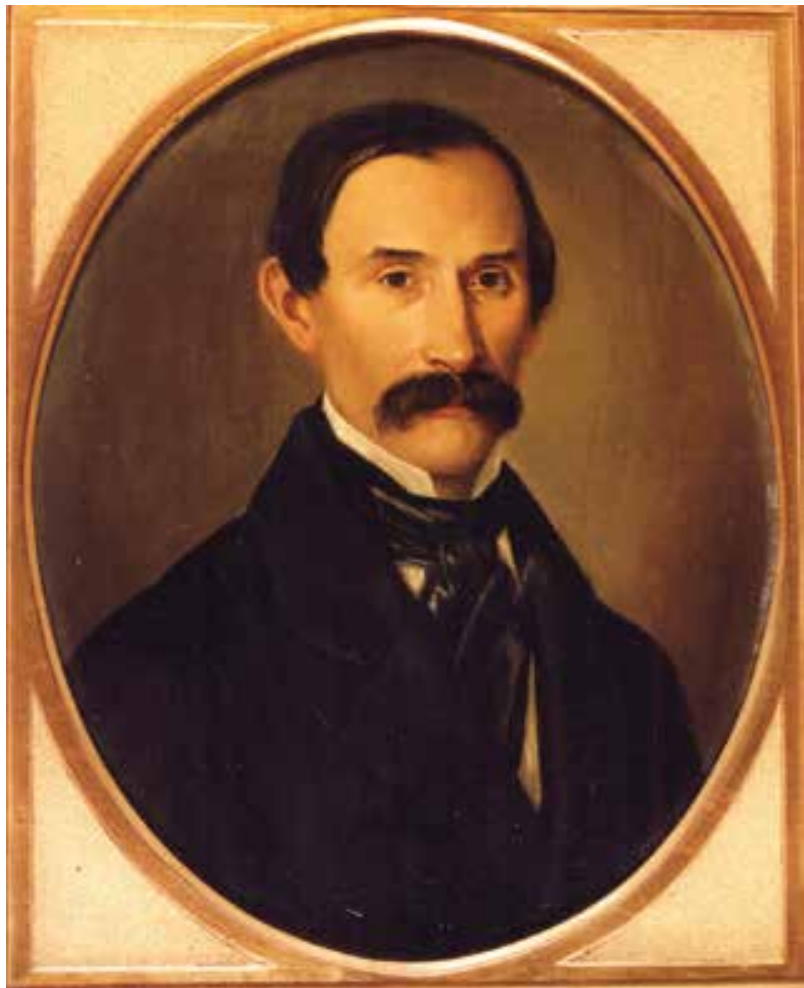

1. Nepoznati slikar, Giovanni Mazzalors, s. a., ulje na platnu, privatno vlasništvo, Trst / Unknown painter, Portrait of Giovanni Mazzalors, oil on canvas, private collection, Trieste

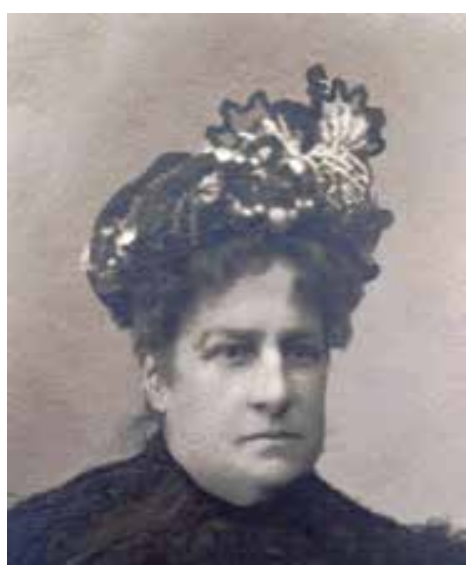

3. Emilija kontesa de Smecchia, rođ. Mazzalors, Carolinina kći, oko 1875., nepoznati fotograf, privatno vlasništvo, Trst / Emilija Countess de Smecchia née Mazzalors, Carolina's daughter, ca. 1875, unknown photographer, private collection, Trieste

više imenjakinja (isto ime i prezime) portretirane gospođe. ${ }^{7}$ U svakom slučaju, možemo pretpostaviti da je Carolina Hassmann rođena u Njemačkoj ili Austriji između 1810. i 1820. godine. Udala se, nedugo prije 1840 . godine, za talijanskog veleposjednika i, vjerojatno, industrijalca Giovannija Mazzalorsa (sl. 1) koji je, prema obiteljskoj predaji, posjedovao velika imanja u dolini rijeke Po. No čini se da

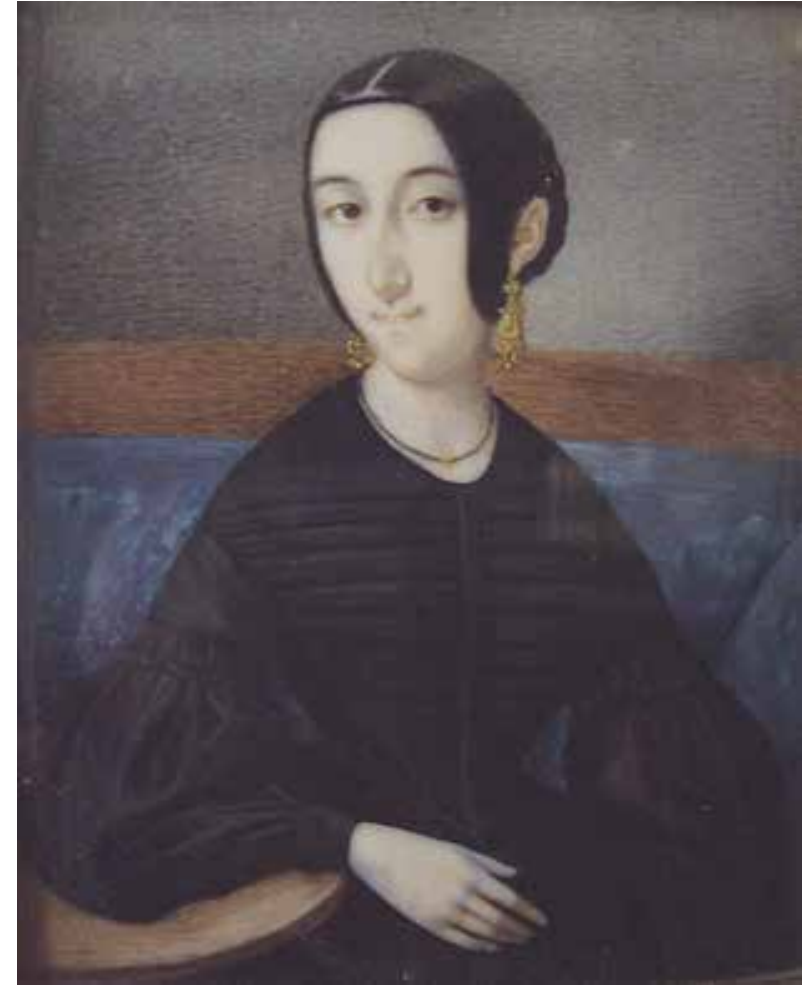

2. Andrea de Castro, Carolina Mazzalors-Hassmann, oko 1840. tempera na bjelokosti, privatno vlasništvo, Trst / Andrea de Castro, Carolina Mazzalors-Hassmann, ca. 1840, tempera on ivory, private collection, Trieste

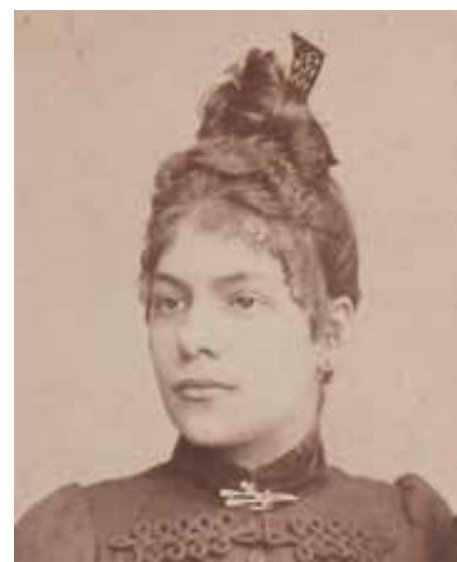

4. Stanislava Radoničić, rođ. kontesa de Smecchia, Carolinina unuka, oko 1890., Sebastianutti \& Benque, privatno vlasništvo, Trst / Stanislava Radoničić née Countess de Smecchia, Carolina's granddaughter, ca. 1890, Sebastianutti \& Benque, private collection, Trieste

s potomstvom nisu imali sreće, na što možda upućuje i sačuvana portretna minijatura $s$ prikazom mlade gospođe Mazzalors-Hassmann u crnini (sl. 2). Jedini potomak imućnih supružnika bila je kći Emilija, rođena u Trstu 8. kolovoza $1840 .{ }^{8}$ Moguće zbog komplikacija nakon poroda, Carolina Mazzalors-Hassmann preminula je nedugo nakon rođenja kćeri, 23. listopada 1840. godine. ${ }^{9}$ Emilija Mazzalors 


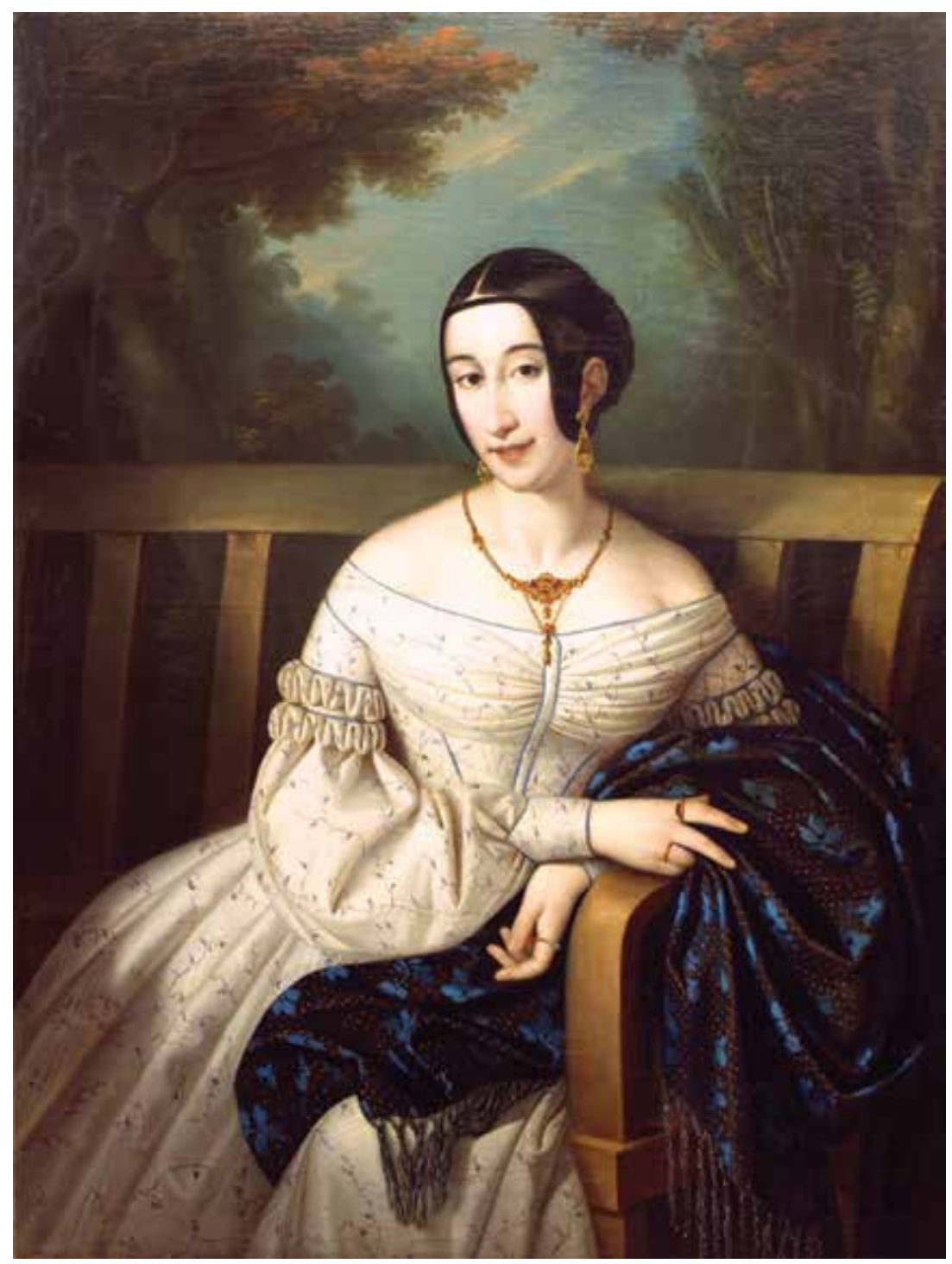

5. Mihael Stroj, Portret Caroline Mazzalors-Hassmann, oko 1840., ulje na platnu, Pomorski muzej Crne Gore, Kotor (foto: Dragutin Radimir) / Mihael Stroj, Portrait of Carolina Mazzalors-Hassmann, ca. 1840, oil on canvas, Maritime Museum of Montenegro, Kotor (photo: Dragutin Radimir)

je udajom za konta Stanislava Smeću (Baošić, 1834. - Trst, 1901.) dobila prestižni naslov kontese de Smecchia (Smeća), a njezin suprug, potomak stare i ugledne ali ekonomski iscrpljene peraške plemenitaške obitelji, zavidnu imovinu u obliku miraza. Iako je brak Emilije i Stanislava Smeće bio iniciran obostranim interesom, bio je iznimno plodan $\mathrm{u}$ potomstvu jer je Carolinina kći jedinica u tom braku rodila četrnaestero djece (sl. 3-4). No, unatoč brojnosti od njih danas više nema muških potomaka. ${ }^{10}$

Portret Caroline Mazzalors-Hassmann krasio je salon tršćanskog doma obitelji Mazzalors, potom ga je Carolinina kći Emilija udajom prenijela u posjed kuće De Smecchia. U inventaru obiteljskih dobara sastavljenom, vjerojatno kod podjele imovine, u Trstu tijekom 1915. godine od strane njezina prvorođenca, grofa Ivana Smeće (Giovanni conte
Smecchia), nalazimo popis obiteljskih slika, a među njima i portret Caroline Mazzalors-Hassmann u prirodnoj veličini, posjednutoj na klupi (Ritratto di Carolina Mazzalors-Hassmann grandezza naturale seduta sopra una scanno. Madre di Emilia Co: Smecchia). ${ }^{11}$ Prema zabilješci, slika je iz Emilijina vlasništva prešla u posjed njezina najmlađeg sina Marija, ali je, čini se, poslije ipak pripala Ivanovim potomcima, od kojih ju je preuzela gospođa Nada Radimir te donirala kotorskom muzeju. Prvi restauratorski zahvat učinjen je od strane konzervatora Pomorskog muzeja Crne Gore prilikom kojeg je platno skinuto s izvornog podokvira na kojem, navodno, nije bilo nikakvih zapisa ili oznaka. Slika je poslije, tijekom 2014., temeljito restaurirana u Centru za konzervaciju i arheologiju Crne Gore - Podružnom odjeljenju Kotor, ${ }^{12}$ te je potom uključena u stalni postav muzeja (sl. 5). 


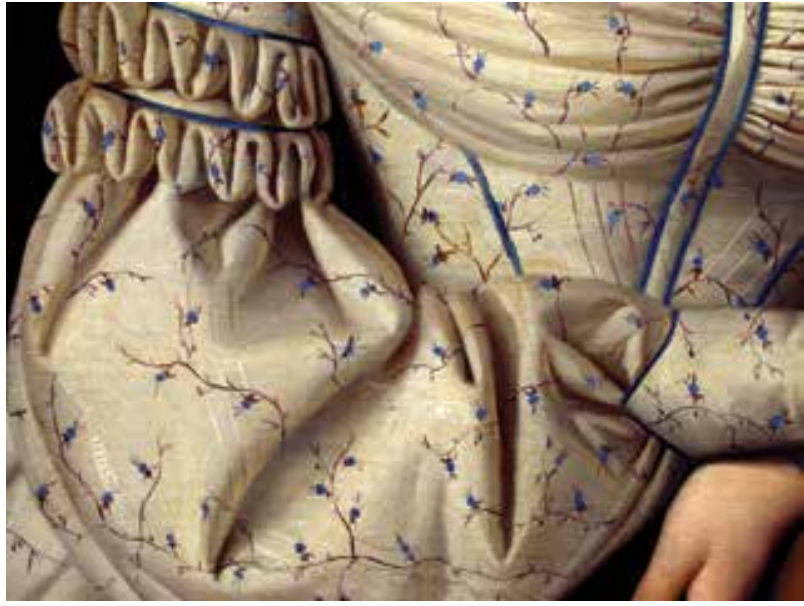

6. Mihael Stroj, Portret Caroline Mazzalors-Hassmann, detalj haljine (Arhiv CKR CG, Kotor; foto: D. Radimir) / Mihael Stroj, Portrait of Carolina Mazzalors-Hassmann, detail of the dress (Archive CKR CG, Kotor, photo: D. Radimir)

Portret Caroline Mazzalors-Hassmann (ulje na platnu, $117 \times 88 \mathrm{~cm}$; Kotor, Pomorski muzej Crne Gore, RZ 2503) ${ }^{13}$ svakako spada u reprezentativne slike svoga žanra, ne samo po motivu - prikazu raskošno odjevene dame dostojanstvena držanja, nego i po dimenzijama platna.

Na vrtnoj klupi smeđih tonova smješten je otmjeni lik mlade žene u svijetloj haljini s motivom grančice s plavim cvjetovima te ukrasima na rukavima u obliku valovitih nabora. Tkanina haljine, bogato nabrane u struku, a posebno naglašeni nabori na širokim rukavima, naslikana je posebnom pozornošću i vrsnoćom (sl. 6). Oval, blago zakrenutoga, duguljastog lica, vrlo svijetlog inkarnata i gotovo porculanske površine, uokviren je glatko počešljanom crnom kosom iz koje proviruje uho s velikom visećom naušnicom. Kosa, iza skupljena u punđu, povezana je tankom crnom vrpcom. Portretirana dama specifičnim izrazom lica kao i delikatno položenim rukama i prstima pomalo ostavlja dojam osobe dalekoistočnog podrijetla. Izražajnim licem, suzdržanog osmijeha, dominiraju tamne oči pod lukovima crnih obrva. Portretirana, karakterno, odaje osobu vesele naravi, otvorena i znatiželjna duha (sl. 7). Ne samo odjeća nego i nakit naslikan je s velikim umijećem. Širokim dekolteom, s obnaženih ramena, spušta se raskošna zlatna ogrlica s dragim kamenjem (sl. 8). Prekrižene ruke, s elegantnim prstenjem, oslanjaju se na bočni naslon klupe preko kojeg je prebačen tamni šal sa svijetloplavim cvjetnim uzorkom, izraženih nabora. Iza klupe s posjednutom damom pruža se romantični krajolik u kojem, među zeleno-smeđim krošnjama drveća, proviruje plavo nebo s pokojim bijelim cirusom (sl. 9). Sam lik portretirane gospođe, obasjan sunčevim svjetlom, zrači toplinom. Portret slikan zanatskom vrsnoćom, u načinu bečkog bidermajera - intimističkoga građanskog slikarstva,

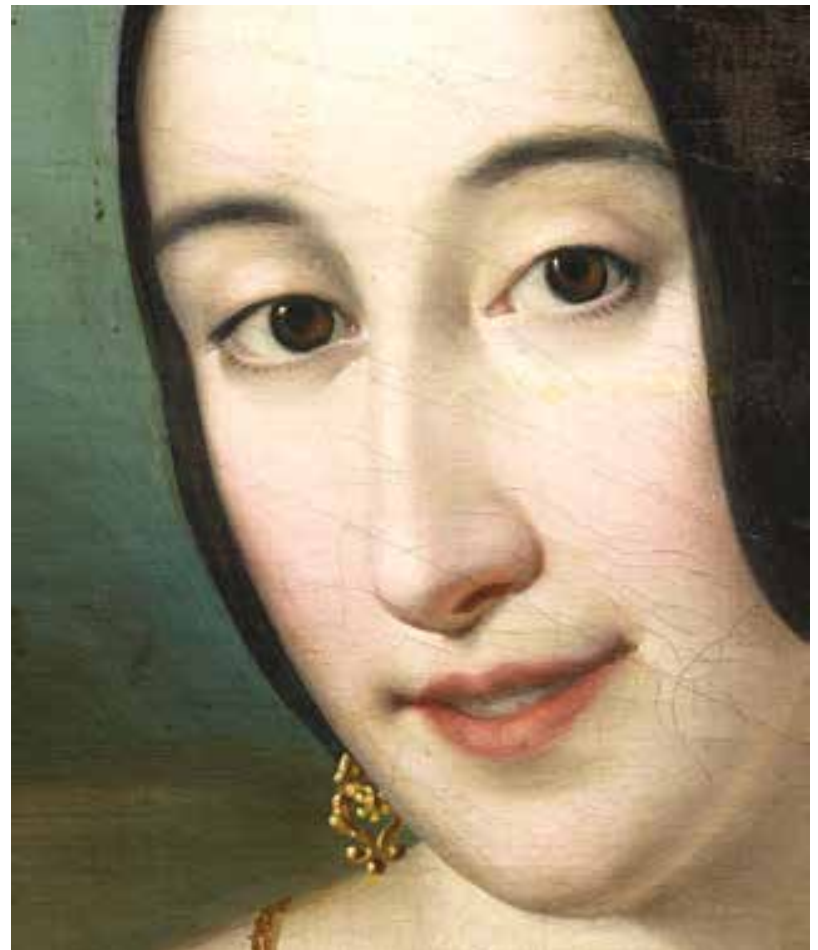

7. Mihael Stroj, Portret Caroline Mazzalors-Hassmann, detalj lica (Arhiv CKR CG, Kotor; foto: D. Radimir) / Mihael Stroj, Portrait of Carolina Mazzalors-Hassmann, detail of the face (Archive CKR CG, Kotor; photo: D. Radimir)

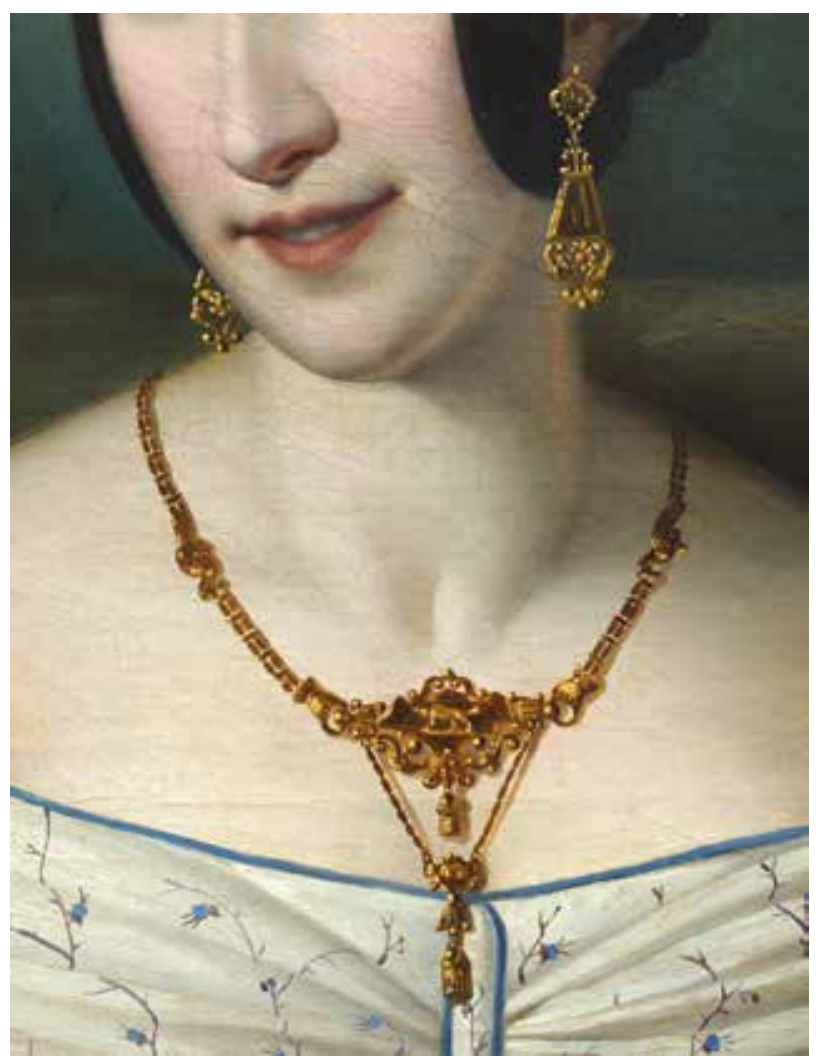

8. Mihael Stroj, Portret Caroline Mazzalors-Hassmann, detalj s nakitom (Arhiv CKR CG, Kotor; foto: D. Radimir) / Mihael Stroj, Portrait of Carolina Mazzalors-Hassmann, detail of the jewellery (Archive CKR CG, Kotor; photo: D. Radimir) 


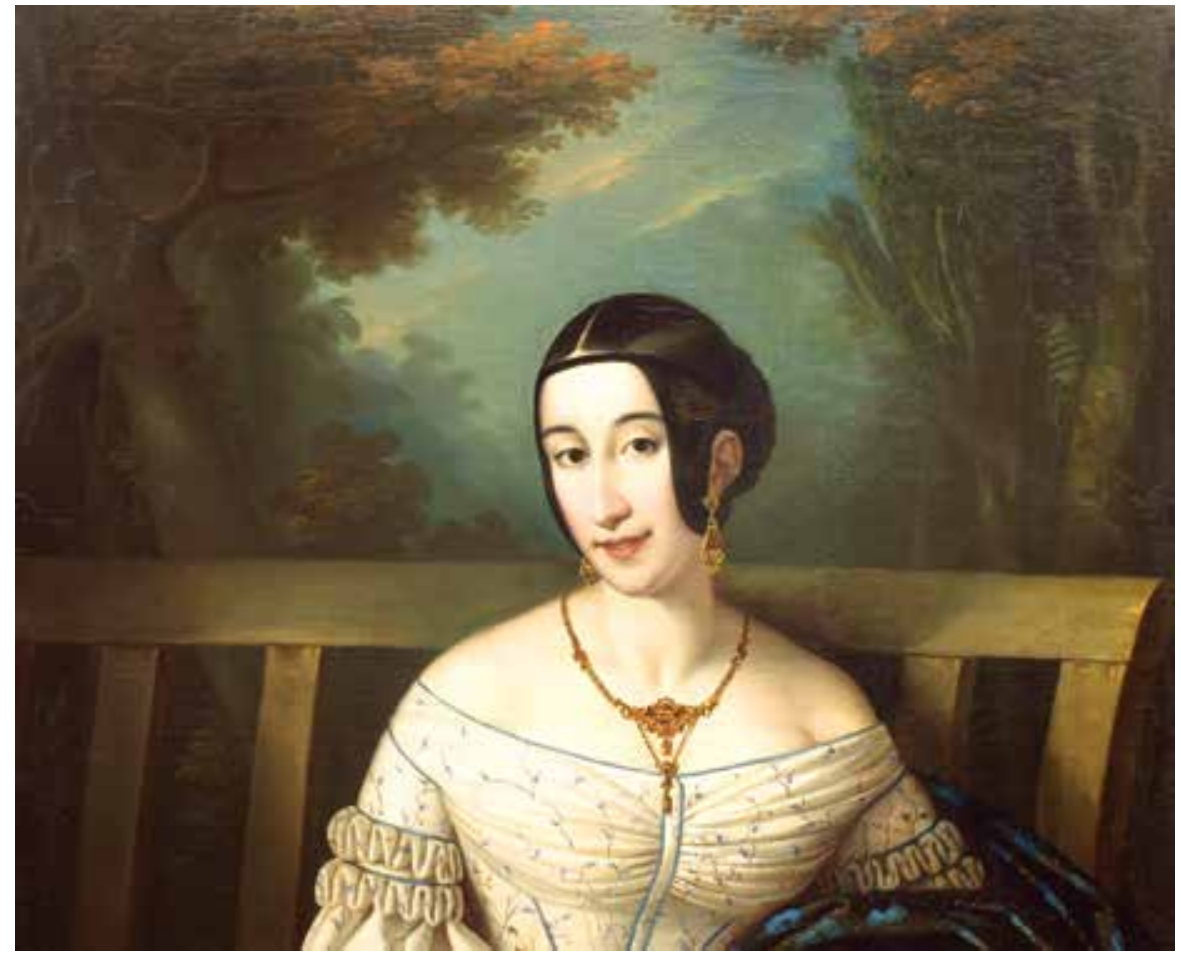

9. Mihael Stroj, Portret Caroline Mazzalors-Hassmann, detalj poprsja s pejzažom u drugom planu (Arhiv CKR CG, Kotor; foto: D. Radimir) / Mihael Stroj, Portrait of Carolina MazzalorsHassmann, detail of the chest with landscape in the background (Archive CKR CG, Kotor; photo: D. Radimir)

ističe se dekorativnošću, a u manjoj mjeri nosi i psihološki karakter prikazane dame. Ne samo figura portretirane dame nego cjelokupno djelo ima romantičarski prizvuk. Iako nesigniran, ovaj portret iznimne kvalitete smatramo radom slovenskog slikara Mihaela Stroja (Ljubno u Gorenjskoj, 1803. - Ljubljana, 1871.), najistaknutijeg slikara klasicizma i bidermajera u Hrvatskoj, u kojoj je boravio i slikao, nakon bečke Akademije, od 1830. do povratka u rodnu Sloveniju godine $1842 .{ }^{14} \mathrm{Za}$ tu atribuciju nalazimo uporište u komparaciji s potpisanim portretima ovog autora iz muzejskih i privatnih zbirki, i to sličnošću primijenjene kompozicije, jasnom i profinjenom modelacijom, kao i Stroju svojstvenim elementima iako neke nalazimo i u djelima drugih autora njegova doba i područja djelovanja, primjerice djelima Jožefa Tominca, ${ }^{15}$ istaknutog portretista tršćanskog građanstva, ili Ferdinanda Georga Waldmüllera ${ }^{16}$ koji je na Stroja neosporno utjecao.

Analogiju u postavu tijela mlade žene, osobito u zaokrenutom položaju glave i poprsja, nalazimo na izrazito romantičnom i profinjenom portretu Marije Svetič (ulje na platnu, $95 \times 79 \mathrm{~cm}$; Ljubljana, Narodna galerija, NG S 365), ${ }^{17}$ signiranom Strojevu djelu (sign. d. d.: Stroy. gemalt / 841.) naslikanom 1841. godine (sl. 10). Upravo ta jedinstvena i čudesna gradnja kompozicije koja je, u eleganciji i »muzikalnosti linija ${ }^{18}$ prisutna i na portretu Caroline

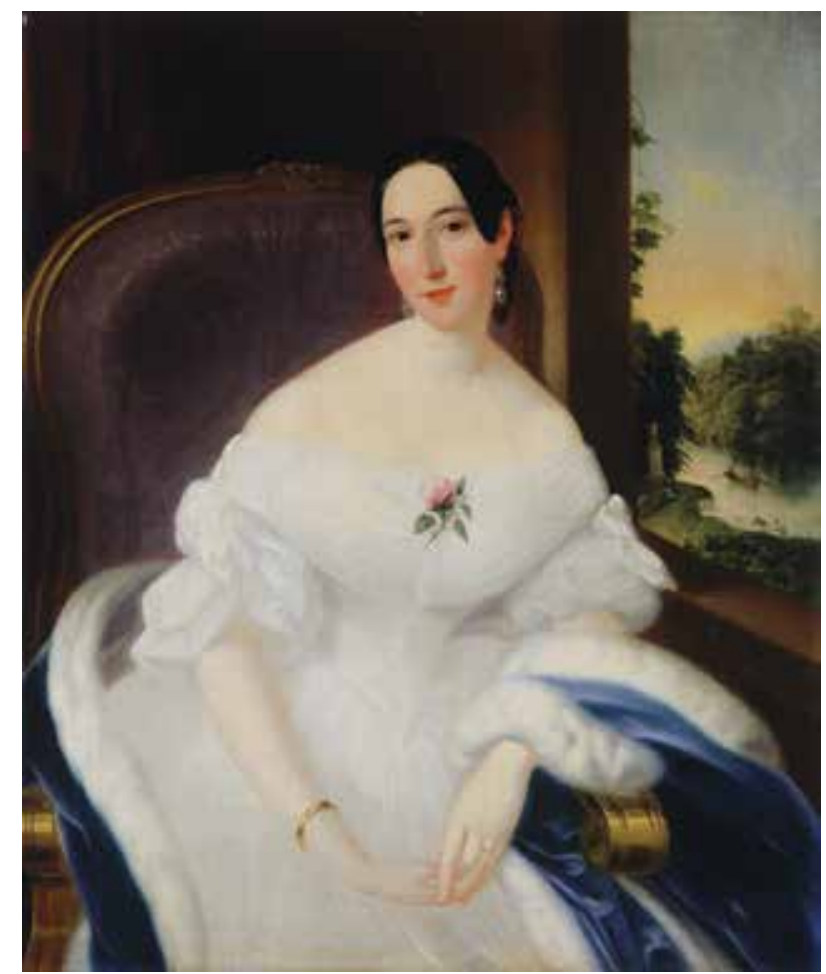

10. Mihael Stroj, Marija Svetič, 1841., ulje na platnu, Narodna galerija, Ljubljana (foto: Bojan Salaj) / Mihael Stroj, Marija Svetič, 1841, oil on canvas, National Gallery of Slovenia, Ljubljana (photo: Bojan Salaj) 


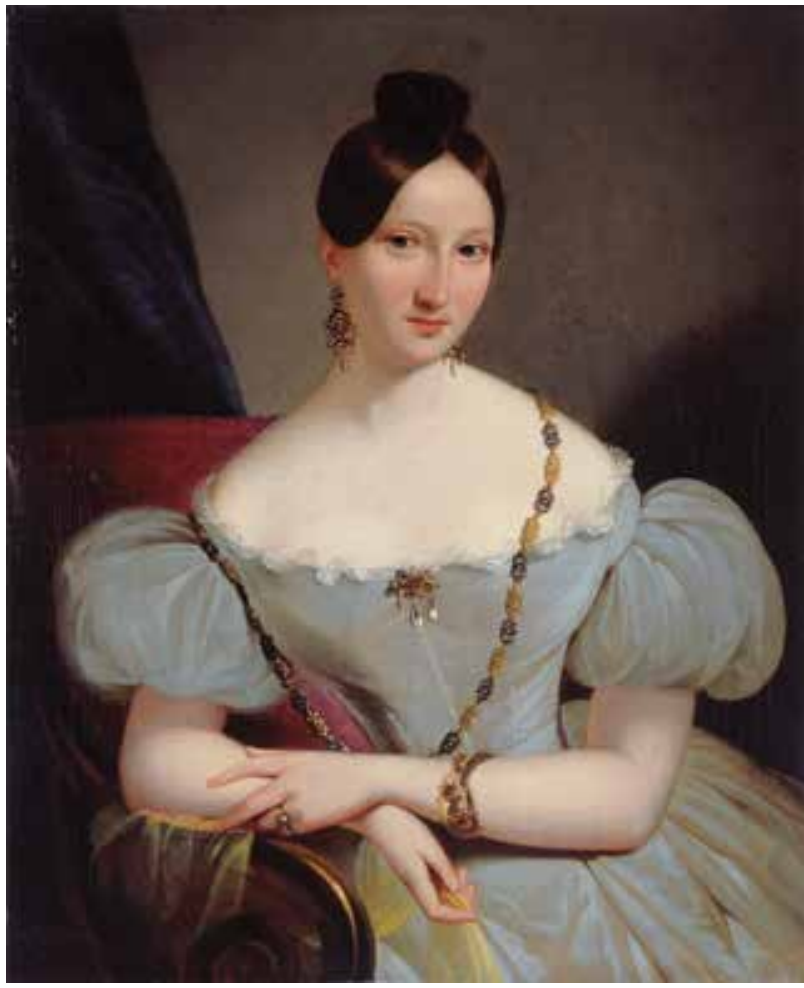

11. Mihael Stroj, Portret neznanke / Portret žene Aleksandra Vilharja, oko 1835., ulje na platnu, Narodna galerija, Ljubljana (foto: B. Salaj) / Mihael Stroj, Portrait of an Unknown Woman / Portrait of Aleksandar Vilhar's Wife, ca. 1835, oil on canvas, National Gallery of Slovenia, Ljubljana (photo: B. Salaj)

Mazzalors-Hassmann, izdiže oba ova rada do visoke razine bidermajerskog portreta. Istu je kompoziciju, naglašeno lijepih linija, Stroj ponovio oko godine 1855. slikajući portret slovenske pjesnikinje i spisateljice Luize Pesjak (Ljubljana, Narodna galerija), ali sa znatno raskošnijim dekorativnim elementima - nakita i cvjetnog aranžmana. Na oba ova Strojeva portreta, a također i na Tominčevu ranijem (1840.) portretu supružnika Piergiacoma i Marije Leva (Trst, privatna zbirka), ${ }^{19}$ ruke s delikatno isprepletenim prstima identično su postavljene i modelirane, a činjenica da taj detalj nalazimo i na nešto ranijem portretu Dvije sestre (nekoć: New York, Colnaghi) francuskog slikara Édouarda Louisa Dubufea upućuje na to da je problematika utjecaja i preuzimanja tuđih formi složenija nego se čini. ${ }^{20} \mathrm{U}$ pogledu drugog plana naše slike (portret Hassmann), također i na spomenutom ljubljanskom portretu Marije Svetič u pozadini ženskog lika nalazimo romantični krajolik, ali je on u ovom slučaju opsegom reduciran na otvor prozora, desno od prikazanog lika. Vidljiva je sličnost i u načinu slikanja elemenata lica na oba portreta, posebno očiju te oblikovanja volumena nosa, kao i usana koje su na portretu Caroline Mazzalors-Hassmann jače razvučene $\mathrm{u}$ diskretan no pomalo prostodušan osmijeh.
Na Strojevu nepotpisanom ali likovno značajnom portretu elegantne dame odjevene u ljubičastu lepršavu haljinu, platnu punom svjetla i svježine, koji Anka Simić-Bulat uvodi u katalog Strojevih djela kao Portret supruge Aleksandra Vilhara ${ }^{21}$ a u matičnoj je zbirci registriran pod nazivom Portret neznanke / Portret žene Aleksandra Vilharja (ulje na platnu, $73,5 \times 58 \mathrm{~cm}$; Ljubljana, Narodna galerija, NG S 361), nastalom oko 1835. godine, portretirana mlada žena izražajnog lica i pomalo zamišljenog pogleda postavljena je u sličan položaj kao i Carolina Mazzalors-Hassmann. Identično je oslonjena na rukohvat fotelje, ali zrcalno suprotno našem portretu. No specifičan položaj i modelacija stiliziranih ruku gotovo su istovjetni na oba portreta (sl. 11). Taj karakterističan prekriženi položaj ruku s elegantno postavljenim prstima nalazimo i na Strojevim portretima Antonije Lipovčić-Werner iz 1837. godine (Zagreb, privatno vlasništvo), ${ }^{22}$ Terezije Nossan-Valpót iz 1838. (Zagreb, Muzej za umjetnost i obrt ) ${ }^{23}$ Katarine Hudovernik-Kanduč, oko 1845. (nekoć: obitelj Hudovernik, Ljubljana) ${ }^{24}$ (sl. 12), portretu Gospođa u crnom iz 1848. (nekoć u zbirci D. Vajde, Zagreb) ${ }^{25}$ i također na drugom Strojevu, nešto ranijem, portretu Luize Pesjak-Crobath (nepoznati vlasnik; ulje na platnu, 103,5 × $81,5 \mathrm{~cm}$ ), ${ }^{26}$ potpisanom i datiranom u 1850. godinu (sign. $d$. 1.: Stroy. pinx: 850 ). Na posljednjem navedenom nalazimo izrazitu srodnost s kotorskim portretom: u postavu i držanju tijela, položaju glave, razmještaju elemenata kao i tretiranju inkarnata te osvjetljenju. Draperija je drugačije tretirana jer je riječ o različitim vrstama tkanina, na portretu L. Pesjak haljina je svilena, no također majstorski naslikana (sl. 13). Zanimljivo je da, uz iznimku kotorskog (i onog Antonije Lipovčić), na svim ostalim Strojevim portretima s ovako postavljenim rukama, portretirana prstima spuštene ruke pridržava svileni šal ili maramu, u jednom slučaju sklopljenu lepezu (Luiza Pesjak). Takav položaj ruku nalazimo na samo jednom portretu u, posredstvom literature dostupnom nam, opusu Jožefa Tominca, na platnu Portret Fanny Preintsch, ${ }^{27}$ no i njega je A. Quinzi, u slikarevoj monografiji, svrstao među Tominčeva djela s dvojbenom ili pogrešnom atribucijom. ${ }^{28}$ Međutim, kada je u pitanju sama modelacija ruku, moramo primijetiti da su one na portretu Caroline Mazzalors-Hassmann načinom oblikovanja možda bliže Tomincu nego Stroju koji je većinom slikao elegantnije ruke dugih tankih prstiju. Posebnu sličnost dosad nepoznatoga kotorskog portreta možemo uočiti s izvrsnim portretom Terezije Nossan-Valpót (ulje na platnu, $81 \times 63 \mathrm{~cm}$; Zagreb, Muzej za umjetnost i obrt, MUO 14749), signiranom i datiranom u 1838. godinu (sign. d. 1.: Stroy. pinx: 1838.). ${ }^{29}$ Ona se očituje u specifičnom tretiranju inkarnata koji zrači bjelinom i krhkošću porculana, $u$, već istaknutom, identičnom postavu ruku (kojima rukavice dodatno ističu eleganciju), osobito poluotvorenih prstiju lijeve šake te u oblikovanju frizure. No, dok kompozicija na portretu Mazzalors-Hassmann zrači gracioznošću, a Carolinin lik otvorenošću 

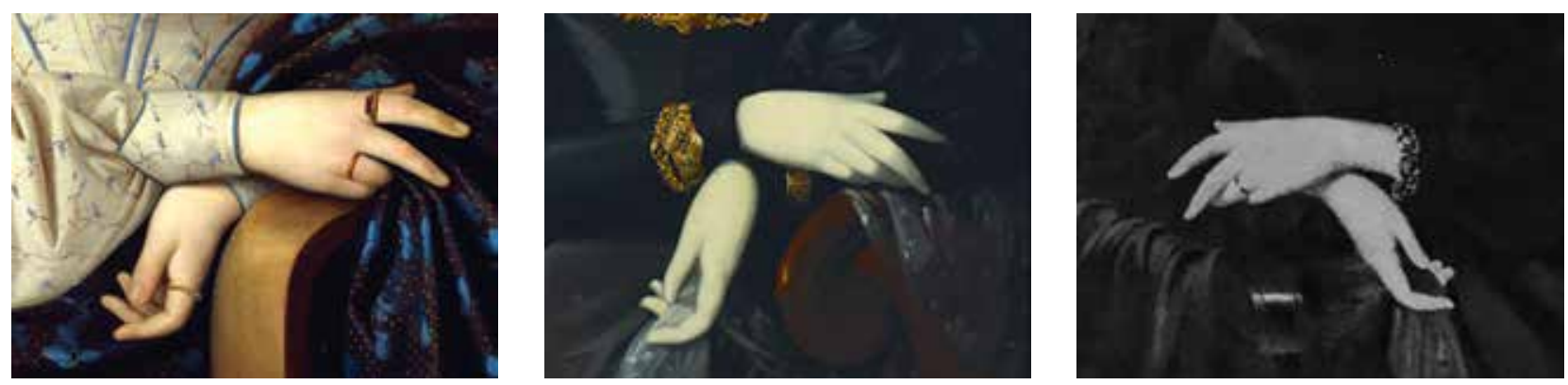

12. Mihael Stroj, detalj ruku: Portret Caroline Mazzalors-Hassmann, oko 1840.; Portret Terezije Nossan-Valpót, 1838.; Portret Katarine Hudovernik-Kanduč, oko 1845. / Mihael Stroj, details of hands: Portrait of Carolina Mazzalors-Hassmann, ca. 1840; Portrait of Terezija Nossan-Valpót, 1838; Portrait of Katarina Hudovernik-Kanduč, ca. 1845

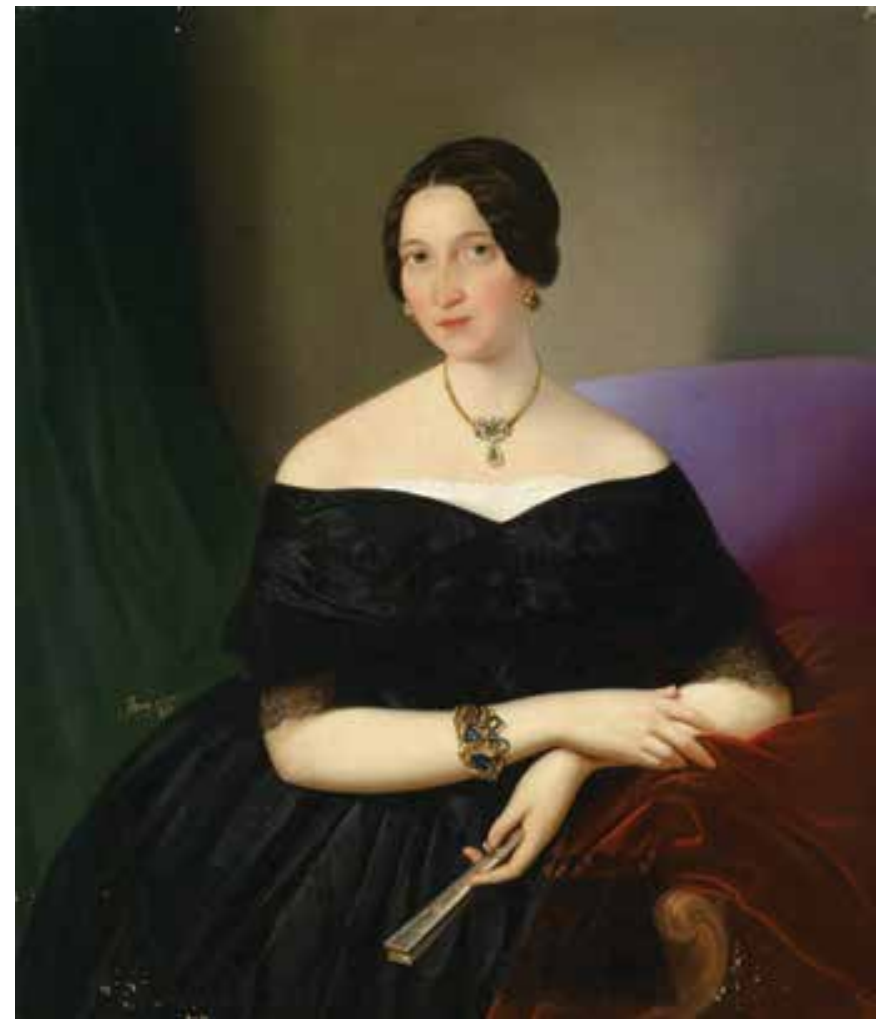

13. Mihael Stroj, Portret Luize Pesjak-Crobath, 1850., ulje na platnu, nepoznati vlasnik (preuzeto s: URL: www.liveinternet.ru, 2015.) / Mihael Stroj, Portrait of Luiza Pesjak-Crobath, 1850, oil on canvas, unknown owner (source: www.liveinternet.ru, 2015)

prema promatraču, portret gospođe Nossan-Valpót odiše strogošću, a sam izraz stanovitom distanciranošću (sl. 14). Na portretu Caroline Hassmann vlada »ravnopravnost" svih elemenata rezultirajući usklađenom cjelinom kojoj ne nedostaje ni pejzaž u pozadini, a sama slika kromatski je bogatija te manje opterećena dekorativnim elementima $\mathrm{u}$ obliku zlatnog nakita.

U čitavom opusu Mihaela Stroja gotovo da ne nalazimo krajolik s tako bujnom vegetacijom kakav je na kotorskom

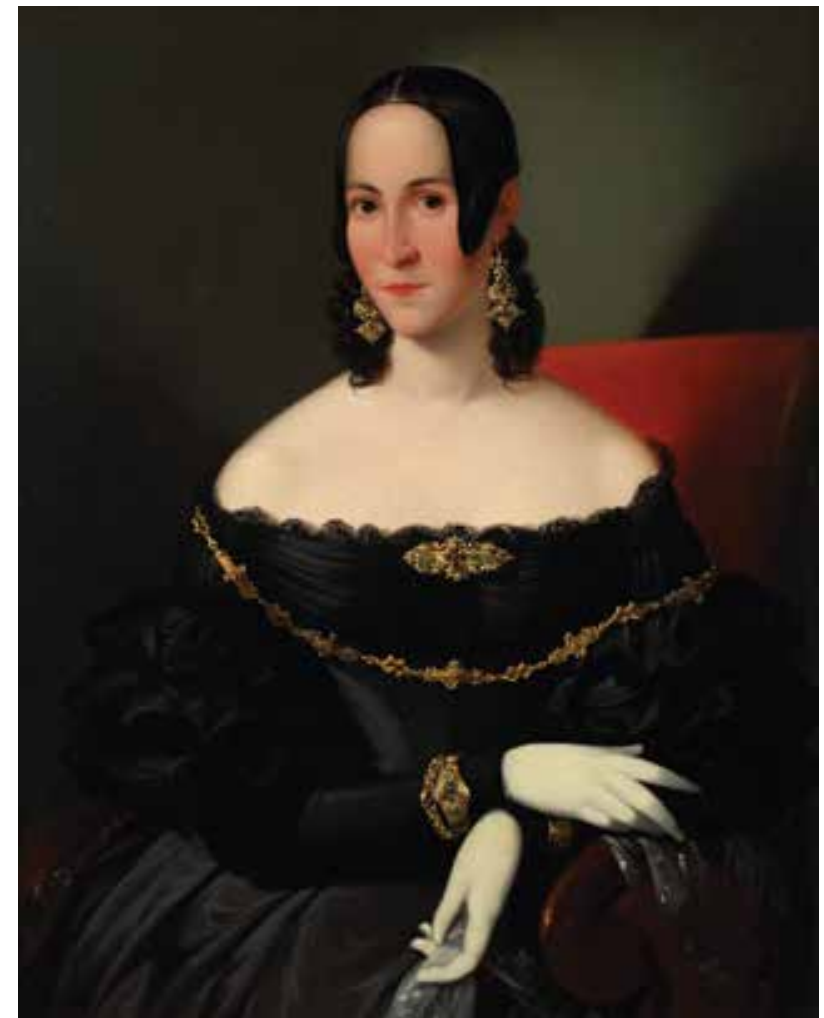

14. Mihael Stroj, Portret Terezije Nossan-Valpót, 1838., ulje na platnu, Muzej za umjetnost i obrt, Zagreb (foto: Srećko Budek) / Mihael Stroj, Portrait of Terezija Nossan-Valpót, 1838, oil on canvas, Museum of Arts and Crafts, Zagreb (photo: Srećko Budek) portretu. Uostalom, pejzaž nije čest na Strojevim platnima. Većina portretiranih dama smještena je u interijeru, a iza njih nalazimo tek tamne zastore i sjene na zidovima. Rjeđe se kroz otvoreni prozor nazire krajolik. Šumski gustiš koji se proteže iza leđa posjednute gospođe Mazzalors-Hassmann, zajedno s nebom koje se promalja među razlistanim krošnjama drveća doprinosi začudnosti samog lika portretirane. Osim što u promatraču budi znatiželju, taj krajobraz daje dodatnu romantičarsku notu cjelokupnom djelu (vidi sl. 9). 
Vegetacija toplog kolorita na Strojevim portretima rjeđe je prisutna, češće nalazimo sumorne krajobraze poput onog na portretu Janeza Svetiča (Ljubljana, Narodna galerija). ${ }^{30}$ No, takvi su detalji često preuzimani, pa ne čudi da modeliranje $i$ kolorit vegetacije slične kotorskom portretu nalazimo i kod drugih tadašnjih slikara Strojeva područja djelovanja (F. G. Waldmüller, F. von Amerling, N. Schiavoni, G. Pagliarini, i dr.) pa uostalom i kod Jožefa Tominca, primjerice na slici Obitelj Sinigaglia (Gorizia, Musei Provinciali) iz 1845., ${ }^{31}$ ili na ranijem portretu Giuseppine Holzknecht (Trst, Civico Museo Revoltella), naslikanom oko 1830 . godine. ${ }^{32}$

Poseban je problem vrijeme i mjesto nastanka portreta. Mogućnost rješavanja pitanja godine nastanka slike pruža nam komparacija modne odjeće i onodobne frizure portretirane dame s drugim portretima toga razdoblja, modnim ilustracijama te ranim fotografijama. Određenu sličnosti s odjećom i frizurom portretirane Caroline Mazzalors-Hassmann nalazimo na više portreta iz 1835., među kojima je i skupni portret Obitelj Kerzmann, izniman rad Ferdinanda Georga Waldmüllera (Beč, Österreichishe Galerie Belvedere).$^{33} \mathrm{Na}$ njemu, u liku gospođe Kerzmann nalazimo sličnosti ne samo $u$ haljini i frizuri nego nam elegancijom i stavom portretiranih dama oba ova studenta bečke Akademije prenose duh građanskog stila koji su uspješno slijedili. Međutim, tek od 1837. učestali su identični ili vrlo slični elementi u oblikovanju ženske frizure i odjeće kakve imamo na portretiranoj gospođi Mazzalors. Tako, sličnu frizuru ali s uzdignutim središnjim dijelom, nalazimo na portretu Emilie Högqvist, djelu Karla Vilhelma Nordgrena iz 1837. godine (Stockholm, Nordiska Museet). ${ }^{34}$ Još je sličnija ona na portretu Josipe Ottenfels-Gschwind, djelu Franza Schrotzberga, nastalom također 1837. (Zagreb, Hrvatski povijesni muzej), koju umjesto crne trake povezuje biserna niska. ${ }^{35}$ Identičnu frizuru nalazimo na desnoj figuri dvostrukog portreta umjetnikovih kćeri Pauline i Eveline Schoppe, djelu Juliusa Schoppea iz 1838. godine. ${ }^{36}$ Također isto oblikovanu frizuru ali sa spuštenom kosom niz vrat, nalazimo na već spomenutom portret Terezije Nossan-Valpót iz iste godine (vidi sl. 14), a gotovo identičnu onoj Caroline MazzalorsHassmann na ilustraciji iz 1839. u povijesnom pregledu onodobne mode. ${ }^{37} \mathrm{Iz}$ literature koja prati povijesne mijene mode nalazimo da je ovakav tip "zalizane« frizure bio u modi i 1840. godine ${ }^{38}$ pa je tako nalazimo i na Strojevu portretu Josipe Vrancaš-Andrassy (Zagreb, privatno vlasništvo) ${ }^{39} \mathrm{i}$ onom Franjice Vlašić (Zagreb, Hrvatski povijesni muzej), ${ }^{40}$ koji mu se sa zadrškom pripisuje, ali i sljedeće 1841. na već opisanom Strojevu ljubljanskom portretu Marije Svetič (vidi sl. 10). Da je takva moda češljanja bila raširena diljem Europe potvrđuje nam fotografija dame u haljini cvjetnog uzorka (Lady in a Flowered Dress) iz 1840-ih snimljena u Škotskoj kamerom jednog od najznačajnijih portretnih fotografa Davida Octaviusa Hilla. ${ }^{41}$ Takva se frizura nosila u Londonu, vidimo prema starim dagerotipijama, i 1843. godine. ${ }^{42}$
Na portretu pruske princeze Marije od Sachsen-Weimara i Eisenacha (Berlin, Staatliche Museen), također radu Juliusa Schoppea iz 1839. godine, nalazimo ne samo isti tip frizure povezan trakom, ali s manje spuštenim zaliscima, nego također i vrlo sličan kroj gornjeg dijela haljine s horizontalnim naborima po sredini i okomito prošivenom trakom. ${ }^{43}$ Slično oblikovanu haljinu, karakterističnih rukava, nalazimo u još jednom pregledu umjetnosti bidermajera, a datirana je oko godine $1838 .{ }^{44} \mathrm{Na}$ skupnom portretu obitelji bogatoga židovskog industrijalca I. J. Wehlea s pogledom na grad Prag, djelu Antonína Macheka nastalom oko godine 1840. (Prag, Národní muzeum), na liku Wehleove kćeri nalazimo jednaku frizuru kao na portretu gospođe Mazzalors, ali i vrlo sličan kroj haljine, doduše $s$ kratkim i drugačije nabranim rukavima. ${ }^{45}$ Izrazita je sličnost u modnim detaljima, ali i u samom postavu portretirane dame s portretom Žene u zelenoj haljini Ferdinanda Georga Waldmüllera (Beč, Österreichishe Galerie Belvedere) iz 1840. godine, ${ }^{46}$ dok nam također Waldmüllerov portret, iz iste godine, Mlada dama pri toaleti (Beč, Wien Museum) ne frizurom, ali odjećom i gracioznošću figure potvrđuje pripadnost portretirane Hassmann bečkom kulturnom krugu, a autora njezina portreta bečkoj slikarskoj školi. ${ }^{47}$ Analogiju u frizuri i odjeći nalazimo na brojnim portretima istog razdoblja ne samo u Austriji i Njemačkoj nego i u Sloveniji, Češkoj i Slovačkoj. U Hrvatskoj pak možemo komparirati i s nizom sačuvanih portretnih minijatura slikara zagrebačkog kruga na kojima nalazimo izrazitu sličnost frizura i odjeće s onima portretirane Caroline Mazzalors-Hassmann što nas pak navodi na misao da je portret mogao nastati upravo na ovom području iako, kako smo već iznijeli, nema podataka da je obitelj Hassmann obitavala u Hrvatskoj. To su, prije svega, dva portreta građanki iz zagrebačke obrtničke obitelji Eisenhut, izvedeni u tehnici tempere na bjelokosti, djela Jakova Stagera ${ }^{48}$ nastala oko 1840 . godine: portreti Marije Eisenhut, rođene Kulik (Zagreb, Muzej za umjetnost i obrt, MUO 11661) (sl. 15) i Fani Eisenhut. ${ }^{49}$ Možemo im pridružiti i portretnu minijaturu istog autora Lik žene u crvenoj haljini, datiranu oko 1846. godine. ${ }^{50}$ Potom dva rada Ljudevita Cetinovića ${ }^{51}$ iz istoga zagrebačkog muzeja, portret Gabrijele Keglević de Buzin iz 1843. godine (ulje na platnu) ${ }^{52}$ i Portret Katarine Čakoje iz 1844. godine (akvarel na bjelokosti; Zagreb, Muzej za umjetnost i obrt, MUO 9858) ${ }^{53}$ (sl. 16). I posljednji u nizu - portret zagrebačke građanke Anke Paulić (ulje na limu), signiran od nepoznatog nam slikara A. Hoelperla, datiran je oko 1840. (Zagreb, Hrvatski povijesni muzej). ${ }^{54}$

Konačno, sličan kroj haljine, sa svim detaljima, nalazimo još i u 1846. godini na figuri posjele gospođe na slici Obitelj Franza I. Kleina od Wiesenberga austrijskog slikara Josefa Weidnera (Velké Losiny, Dvorac Žerotín), ali i uočavamo razliku u frizuri koja mjesto začešljanih zalizaka ima oblikovane uvojke. ${ }^{55}$ 


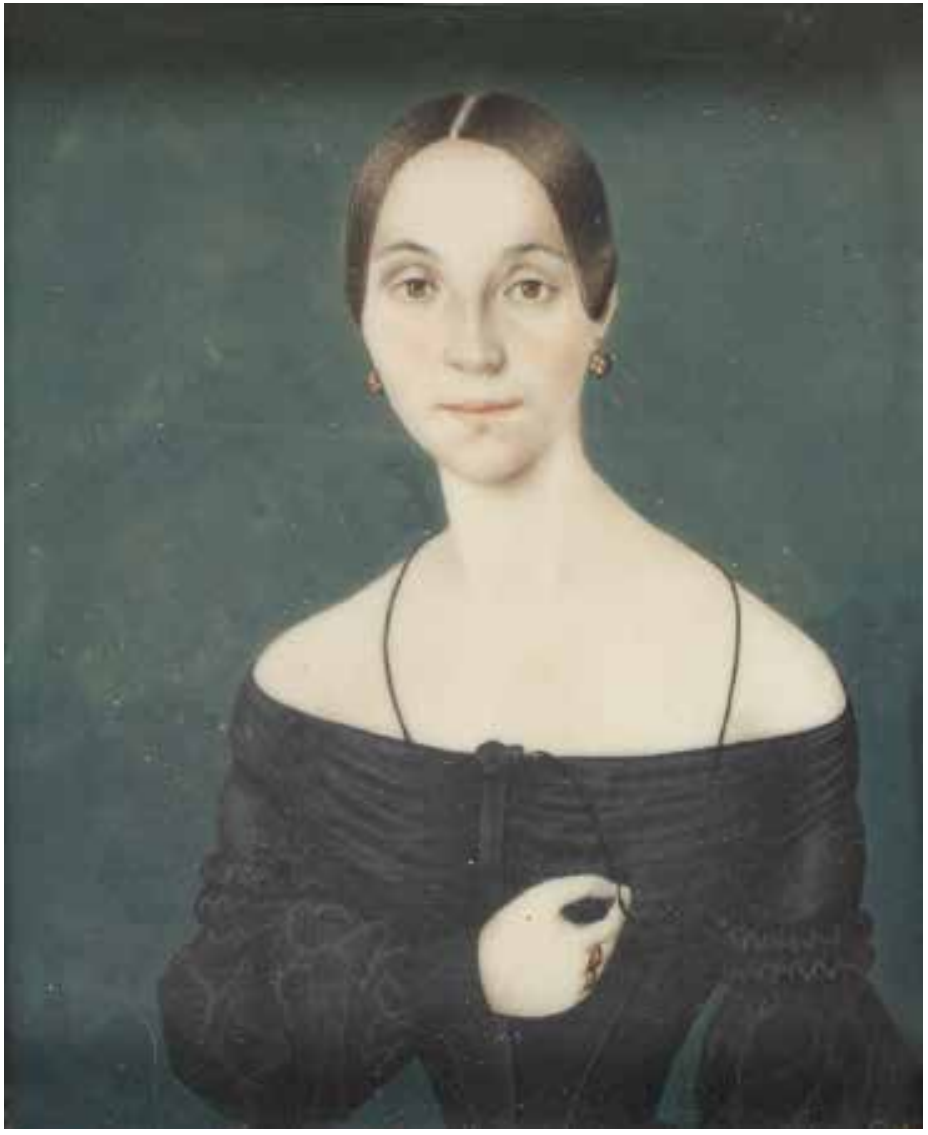

15. Jakov Sager, Portret Marije Eisenhut, oko 1840., tempera na bjelokosti, Muzej za umjetnost i obrt, Zagreb (foto: Vedran Benović) / Jakov Sager, Portrait of Marija Eisenhut, ca. 1840, tempera on ivory, Museum of Arts and Crafts, Zagreb (photo: Vedran Benović)

Kako smo već naveli, Carolina Mazzalors-Hassmann preminula je 1840. godine, nakon rođenja jedinice - kćeri Emilije. Uzevši u obzir dob portretirane te godine nastanka najsličnijih radova pretpostavljenog autora, ali i tadašnju modu frizure i odjeće, prema gornjem slijedu, portret je mogao biti naslikan između 1838. i 1840. godine, ako je rađen za života, možda i uz poziranje portretirane dame. U tom bi slučaju mogao biti naslikan i prije Carolinine udaje, u mjestu njezina djevojačkog boravka. Toj pretpostavci ide u prilog činjenica da je Stroj 25. svibnja 1838. godine podnio molbu gradskoj upravi u Ljubljani za izdavanje putnog lista za putovanje u inozemstvo, kojoj je sljedeće, 1839., godine dodana primjedba da je riječ o putovanju u Bavarsku, Sasku i Prusku. ${ }^{56}$ No, portret je mogao biti naručen i nakon prerane smrti Caroline Mazzalors-Hassmann, nedugo nakon godine 1840., a kao predložak je mogao poslužiti portret iste gospođe koji je također pripadao obitelji. ${ }^{57}$ Iako nam je dostupan posredstvom nedovoljno kvalitetne fotografije, jasno je kako je riječ o portretnoj minijaturi $(9 \times 7 \mathrm{~cm}) \mathrm{u}$ tehnici tempere na bjelokosti, a usporedbom sličnih radova

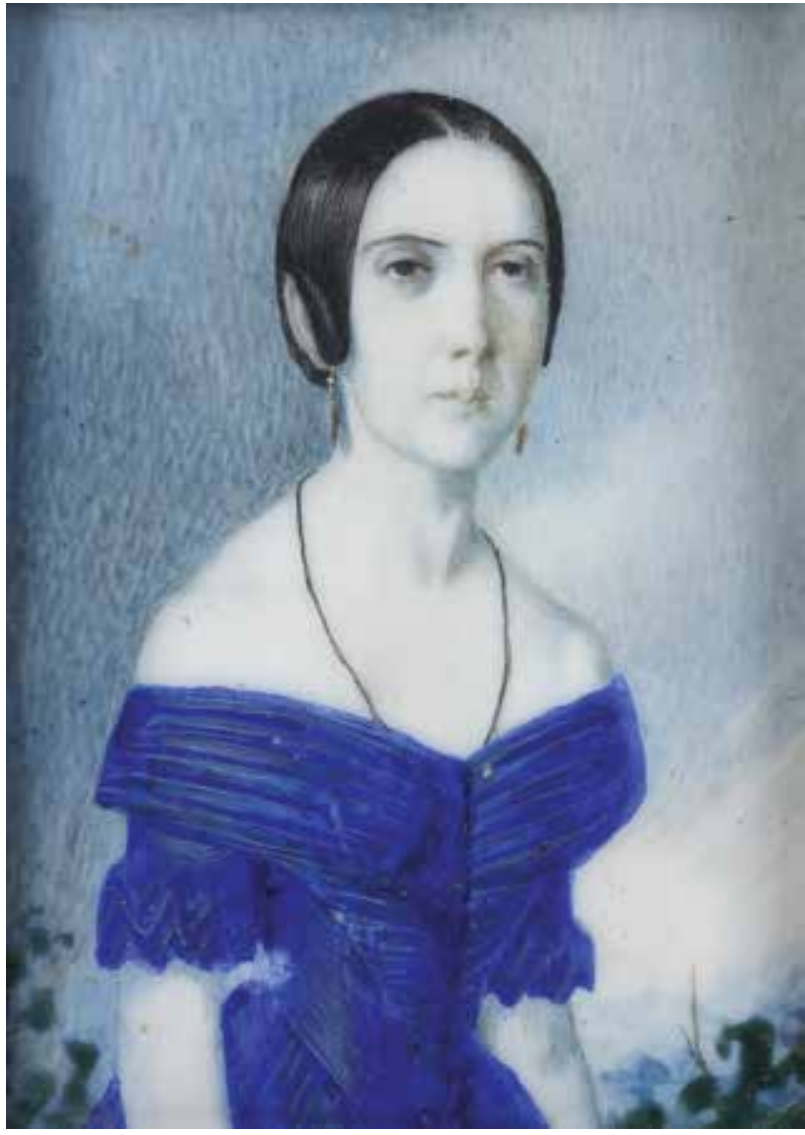

16. Ljudevit Cetinović, Portret Katarine Čakoje, 1844., akvarel na bjelokosti, Muzej za umjetnost i obrt, Zagreb (foto: V. Benović) / Ljudevit Cetinović, Portrait of Katarina Cakoja, 1844, watercolour on ivory, Museum of Arts and Crafts, Zagreb (photo: V. Benović)

ustanovili smo (a tomu u prilog ide i kasnije pronađeni zapis u obiteljskom popisu imovine) da je minijatura djelo Andree de Castra (Piran, 1806.-1884.). ${ }^{58} \mathrm{Na}$ njoj portretirana ima vrlo sličan izraz lica i pogled, položaj glave i desne ruke. Štoviše, ima identičnu frizuru i haljinu sličnog kroja, ali crne boje i bez dekoltea (što daje naslutiti da je moguće bila u žalosti) te vrlo slične naušnice, a također je prikazana u sjedećem položaju, u ovom slučaju sjedi na sofi (vidi sl. 2). ${ }^{59}$ Ova iznimna sličnost dvaju portreta dvoji nas između dva moguća zaključka. U prvom bi, u okviru gornje teze, mogli zaključiti da je kotorski portret Caroline MazzalorsHassmann naručen nakon njezine smrti, a naslikan između 1840. i 1844. godine, prema postojećoj portretnoj minijaturi Andree de Castra koja se čuva kod potomaka portretirane dame. U drugom bi slučaju mogli zaključiti da je kotorski portret naslikan za Carolinina života, između 1838. i 1840. godine. Iako nas sačuvani naziv portreta, prema djevojačkom prezimenu portretirane (Hassmann), upućuje da je portret mogao nastati prije Carolinine udaje, u vrijeme eventualnog Strojeva putovanja i kraćeg boravka u njema- 
čkim zemljama, posebno Pruskoj, ipak takvu pretpostavku gotovo dokida činjenica da na oba portreta (kotorskom platnu i tršćanskoj minijaturi) na prstenjaku desne ruke Caroline Mazzalors-Hassmann nalazimo vjenčani prsten. Stoga je portret ipak naslikan nakon njezine udaje i vjerojatnog preseljenja u novu sredinu. Mogao je nastati, prema narudžbi, i u Hrvatskoj, bez izravnog poziranja, prema De Castrovoj minijaturi kao predlošku, ali i za mogućeg Strojeva kratkog boravka u Trstu, prebivalištu obitelj Mazzalors. Strojeva kći Margareta udala se 1865. za tršćanskog »trgovca i kapitalistu« Michelea Cochinija koji je pripadao istom građanskom sloju imućnih tršćanskih veleposjednika kao i Giovanni Mazzalors. Vjerojatno je postojala veza obitelji Stroj s Trstom i prije, jer su se brakovi tada sklapali među, prijateljstvom ili poslom, povezanim obiteljima. A valja spomenuti i podatak da je, prema slikarevu zapisu, gotovo dva desetljeća ranije, godine 1847., Stroj prodao sliku nekom državnom savjetniku iz Trsta. ${ }^{60}$

\section{Zaključak}

Analizom nepotpisane slike Portret Caroline Mazzalors-Hassmann te usporedbom s neupitnim slikarevim djelima iz muzejskih i privatnih zbirki, ovaj dosad nepoznati rad skloni smo pridružiti opusu vrlo plodnoga slovenskog slikara Mihaela Stroja. Na to nas navodi više elemenata. Jedinstvena modelacija (uskog) lica tipična je za Strojev portret. Ona nam je po osvjetljenju možda bliska i Jožefu Tomincu, ali po modelaciji ne, jer su obrazi osoba na Tominčevim portretima oblikovani s jače naglašenom muskulaturom. Prisutan je i Strojev prepoznatljivi tretman inkarnata kojim postiže samo njemu svojstvenu glatkoću, upravo porculanske površine. ${ }^{61}$ I romantični elementi slike, kao i prisutnost određene dekorativnosti svojstveni su Stroju, a također i nedostatak dubljeg poniranja u psihu portretirane dame. Položaj stiliziranih ruku kakav je na portretu gospođe Mazzalors, Stroj je ponovio na desetak svojih potpisanih portreta u razdoblju od 1835. do 1850., dok takav postav ruku u, preko dostupne literature, poznatom nam opusu J. Tominca nalazimo samo na jednom portretu (datiranom oko 1838.), čije se autorstvo, uostalom, drži upitnim. No ipak kod samog modeliranja ruku kao da je izostala »strojevska « gotovo krhka elegancija prstiju. U prilog Stroju ide i postav same figure - uspravno, dostojanstveno držanje i elegancija portretirane dame. Oblikovanje izvanredno naslikane draperije također otvara mogućnost Strojeva autorstva. Neupitna ljepota ovog portreta je i u postignutom skladu između portretirane dame i ostalih elemenata figuracije, posebno s romantičnim krajolikom iz drugog plana, kojim dominira razlistalo drveće. U Strojevu slikarstvu rijetko nalazimo tako bogatu vegetaciju, njegovi su krajobrazi nerijetko reducirani i sumornog ozračja. Uku- pnost dojma kao i iznesena raščlamba prinove kotorskom muzeju, unatoč elementima koji mogu upućivati i na druge autore, navode nas na prijedlog atribucije Portreta Caroline Mazzalors-Hassmann slovenskom slikaru Mihaelu Stroju.

U pogledu datacije slike, slično ili identično oblikovanu frizuru pratimo između 1837. i 1844. godine, a haljinu sličnog kroja nalazimo između 1838. i 1846. Nije moguće sa sigurnošću zaključiti je li portret nastao za života portretirane Caroline Mazzalors-Hassmann (između 1838. i 1840.) ili je naslikan nakon njezine prerane smrti (između 1840. i 1844.), prema portretnoj minijaturi Andree de Castra. Vjenčani prsten na ruci portretirane upućuje da je rad nastao nakon Carolinine udaje. Portret je mogao biti naslikan nakon Strojeva povratka u Sloveniju, ali i u vrijeme slikareva boravka u Zagrebu gdje je, kao najistaknutiji slikar klasicizma i bidermajera, bio vrlo tražen i produktivan, a narudžbe su stizale i iz šire okolice. U nemogućnosti da točno utvrdimo godinu nastanka predlažemo, zasad, dataciju portreta u godine oko 1840.

Prelaskom iz dalekih intimnih prostora potomaka drevne i davno iseljene bokeljske plemićke obitelji Smeća (Smecchia) u stalni postav kotorskog muzeja, plemenitim činom darivanja, portret Caroline Mazzalors-Hassmann, nastao u krugu bečkog bidermajera, postao je predmetom interesa brojnih posjetitelja. Ovim prilogom nadamo se potaknuti i znatiželju struke za ovaj zanimljivi portret vjerujući da ćemo u okviru predloženog autorstva u dogledno vrijeme razriješiti i preostale uz njega vezane nedoumice.

\section{BILJEŠKE}

1 SLAVKO DABINOVIĆ, Povratak u zavičaj: Pomorski muzej Crne Gore u Kotoru priredio izložbu obiteljskog nasljeđa Nade Radimir, Hrvatski glasnik, 118 (2015.), 28-30.

2 Prezime je u novije doba katkada zapisivano, a češće izgovarano i kao Smekja.

3 U obiteljskim zapisima uz ime Caroline Hassmann ne navodi se titula kontese što je dosljedno isticano uz svakog člana obitelji Smeća. No, tituliranje s »nobildonna« od strane tršćanskih potomaka upućuje da je bila plemenita roda.

4 Na pomoći kod pretrage baze prezimena u Hrvatskoj zahvaljujem dr. sc. Melini Lučić, načelnici Odsjeka za gradivo obitelji, pojedinaca i arhivske zbirke Hrvatskoga državnog arhiva, mr. sc. Nikši Lučiću, glavnom uredniku Hrvatskoga biografskog leksikona, a u Sloveniji prof. Goranki Kreačić.

5 Primjerice u Rastattu (pokrajina Baden-Württemberg) 1796. rođen je Johann Hassmann, a zanimljivo je spomenuti i austrijskog slikara, pretežno mitoloških scena, Karla Ludwiga Hassmanna (Beč, 1869.-1933.).

6 Johan Herman Hassmann, sin Petera Wilhelma i Elisabete Königkramer, rođen je 12. svibnja 1766. godine u Lienenu u Pruskoj, a u braku s Annom Catharinom Elisabethom Metger imao je sina Johana Wilhelma. URL: https://www.genealogieonline.nl/en/stamboom-rietveld/I5209.php (26. 10. 2015.).

7 Vidjeti na: www.ancestry.co.uk.

8 Podaci su iz rodoslovlja tršćanskog ogranka obitelji Smeća (Smecchia), međutim u jednom je obiteljskom izvoru zapisano da je Emilija rođena 18. kolovoza. Na uvidu u rodoslovlja te na drugim obiteljskim podacima 
zahvaljujem gospodinu Zoroslavu Radimiru iz Dobrote, srodniku gospođe Nade Radimir, darodavke slike.

9 Prema dokumentu Comune di Trieste - Uff. di Polizia Mortuaria - ACEGA od 9. kolovoza 2011. koji je ljubazno ustupio prijatelj potomaka obitelji Smecchia iz Trsta kapetan Paolo Muner, sahranjena je na tršćanskom groblju Sv. Ane u grobu (0702, polje 4) s obeliskom na kome stoji »FAMIGLIA MAZZALORS E CONTI SMECCHIA«. Prema popisu ukopa, Carolina je prva, ali i jedina osoba s prezimenom Mazzalors koja je sahranjena u tom grobu. U isti je, kasnije, uz brojne članove obitelji Smecchia, pokopana 1875. godine i Maria Hassmann, možda Carolinina majka.

10 Drevni bokeljski plemićki rod Smeća uzdigao se u eri pomorstva na jedra. Ova je peraška obitelj iznjedrila brojne znamenite kapetane i moćne brodovlasnike te pomorskom trgovinom stekla znatno bogatstvo i ugled, a velikim pothvatima i mletački grofovski naslov. Kapetan Vicko Smeća (Perast, 1694.-1762.) istaknuo se kao hrabar pomorac koji je uspješnom pomorskom trgovinom stvorio zavidnu obiteljsku imovinu, a zapamćen je i kao najveći darovatelj svetišta Gospe od Škrpjela, nakon biskupa Andrije Zmajevića. Njegov sin Petar (Perast, 1724.-1767.), kapetan neustrašiva i znatiželjna duha, uspostavio je 1746. godine navom Leon Coronato prvu pomorsku trgovačku vezu Venecije i Baltika te je mletački dužd Pietro Grimani za stečene zasluge 1748. obitelji Smeća dodijelio grofovski naslov (o tome vidi: ŽELJKO BRGULJAN, Zavjetni darovi bokeljskih pomoraca u crkvama Kotorske biskupije, u: Zavjetni darovi bokeljskih pomoraca, katalog izložbe, Muzej za umjetnost i obrt, Zagreb, 2014., 24-25, 34-35). Godine 1764. Smeće su izgradili u Perastu obiteljsku palaču koja dominira gradićem, a jedna je od najvećih u Boki kotorskoj. U 19. stoljeću neki članovi obitelji obnašali su državne službe u obližnjem Kotoru, upravnom središtu zaljeva, a dr. Tripun konte Smeća 1859. i dužnost admirala Bokeljske mornarice. U istom stoljeću Smeće sele u Trst gdje je više članova nastavilo obiteljsku pomorsku tradiciju kao kapetani na Austrijskom Lloydu. Posljednji muški potomak obitelji Smeća, sin Emilijina i Stanislavova prvorođenca Giovannija i Eugenije Luigije Santa Chiesa, Stanislav de Smecchia preminuo je, prema podatku iz obiteljskog rodoslovlja, 1980. godine u Trstu.

11 Memorie sopra la famiglia Conti de Smecchia radunate da me Giovanni Conte Smecchia, Trieste 22 Febrajo 1916, rukopis u posjedu potomaka obitelji Smecchia, str. 62., inv. br. 21. Sa strane je u zabilješci vlasništva navedeno "presso Emilia Co: Smecchia «, a poslije precrtano te je dopisan »Mario Co: Smecchia«, Emilijin najmlađi sin, kao novi vlasnik slike.

12 Radove su izveli Jasminka Grgurević, konzervator-restaurator, Dragutin Radimir, slikar-konzervator, i Slavica Lompar, likovni tehničar u navedenom Centru, kojem dugujem zahvalnost za ustupljene fotografije. 13 Na prvoj fotografiji i tehničkim podacima o slici zahvaljujem kolegama iz Pomorskog muzeja Crne Gore u Kotoru, gospodinu Slavku Dabinoviću, knjižničaru,te kustosici Zbirke slika gospođi Radojki Abramović. 14 Slovenski slikar Mihael Stroj (Stroy) rodio se 30. rujna 1803. u Ljubnom, u pokrajini Gorenjskoj, kao peto dijete Antona i Marije Stroj, rođene Kokal. U dijelu literature (osobito u Hrvatskoj) i pojedinim dokumentima prezime mu nalazimo i u obliku Stroy, a tako se potpisivao i na svojim slikama. Upisao se na Akademiju likovnih umjetnosti u Beču 1822. koju je uspješno okončao, usvojivši solidnu slikarsku vještinu, spreman i za zahtjevne narudžbe. Nakon Akademije, prema bilješci u dnevnom tisku posredstvom koje nudi svoje usluge kao "Porträt und Historienmaler «, 1830. nastanjuje se u Zagrebu gdje boravi do 1842., slikajući, u duhu građanske umjetnosti bidermajera, portrete zagrebačkih građana kao i plemstva po obližnjim dvorcima i kurijama. Osobitosti bečkoga bidermajerskog slikarstva Stroj je u Zagrebu razvio do romantičnog izraza. Da je boravak i rad u Hrvatskoj bio stvaralački plodan potvrđuju i brojni sačuvani portreti, a u Zagrebu mu se i rodila prva kći Otilia 1838. (krštena u crkvi sv. Marije na Dolcu) u vezi s Margaretom Berghaus kojom se oženio 1841. Važno je istaknuti da od te godine pa do 1847. pored portretiranja izvodi i veće radove - sakralne tematike, posebno oltarne pale za župnu crkvu u Novoj Rači kraj Bjelovara te za crkvu u Vugrovcu. Nakon povratka u Sloveniju slijedi zrelo doba Strojeve umjetnosti koje prekida slikareva smrt 19. prosinca 1871. u Ljubljani. O Stroju vidjeti: ANKA
BULAT-SIMIĆ, Mihael Stroy, Društvo historičara umjetnosti Hrvatske, Zagreb, 1967.; KSENIJA ROZMAN, Mihael Stroj 1803-1871, Narodna galerija, Ljubljana, 1971.; BARBARA JAKI, Mihael Stroj, u: Meščanska slika: slikarstvo prve polovice 19. stoletja iz zbirk Narodne galerije, katalog izložbe, Narodna galerija, Ljubljana, 2000., 210-249; GRGO GAMULIN, Mihael Stroy, u: Hrvatsko slikarstvo XIX. stoljeća, sv. 1, Naklada Naprijed, Zagreb, 1995., 68-82; MARIJANA SCHNEIDER, Portreti 1800 - 1870., Katalog muzejskih zbirki IX, Povijesni muzej Hrvatske, Zagreb, 1973., 36, 53, 60, 74, 114, 119; BARBARA JAKI, Bidermajersko slikarstvo iz zbirki Narodne galerije, Ljubljana, u: Slovensko bidermajersko slikarstvo iz zbirki Narodne galerije, Ljubljana, katalog izložbe, Muzej za umjetnost i obrt, Zagreb, 1998., 8-9.

15 Slovensko-talijanski slikar Jožef Tominc, isto i Giuseppe Tominz (Gorizia, 1790. - Gradišče nad Prvačino, 1866.), studirao je u Veneciji i Rimu. Od 1830. djelovao je u Trstu, a nakon 1850. u Goriziji. Iako je slikao biblijske scene većinom za tršćanske crkve, a nekoliko mu radova nalazimo i u crkvama Boke kotorske, proslavio se u portretnom slikarstvu. Portretirao je istaknute pojedince iz tršćanskih i ljubljanskih građanskih obitelji, a njegovi portreti imaju obilježja profinjenog bidermajer slikarstva. O Tomincu vidjeti: ALESSANDRO QUINZI, Giuseppe Tominz, Fondazione CRTrieste, Treste, 2011.; Jožef Tominc, Fiziognomija slike, katalog izložbe, Narodna galerija, Ljubljana, 2002.; BARBARA JAKI, Jožef Tominz, u: Meščanska slika: slikarstvo prve polovice 19. stoletja iz zbirk Narodne galerije, katalog izložbe, Narodna galerija, Ljubljana, 2000., 250-275; MARIJANA SCHNEIDER (bilj. 14), 37, 54; KRUNO PRIJATELJ, Slike Josipa Tominca u Boki Kotorskoj, u: Studije o umjetninama u Dalmaciji I, Zagreb, 1963., 95-98; BORIS VIŽINTIN, Prilog biografijama slovenskih slikara Josipa Tominca, Matije Tomca, Gaspara Götzla i Josefe Štrus, Peristil, II (1957.), 205-209.

16 Ferdinand Georg Waldmüller (Beč, 1793. - Hinterbrühl, 1865.) jedan je od najznačajnijih predstavnika bečkoga bidermajerskog slikarstva. Nakon studija na bečkoj Akademiji, od 1811. do 1814. živio je u Zagrebu gdje je bio u službi bana J. Gyulaya kao učitelj crtanja njegove djece. Ostavio je portrete dviju znamenitih osoba: bana Ignjata Gyulaya i biskupa Maksimilijana Vrhovca (Hrvatski povijesni muzej, Zagreb), a pripisuju mu se portret Franza Gyulaya, banova sina (Moderna galerija, Zagreb), portretna minijatura biskupa Vrhovca (Muzej za umjetnost i obrt, Zagreb) te još nekoliko portreta u privatnim zbirkama. Od 1829. pa do umirovljenja 1857. profesor je na bečkoj Akademiji. Bio je istaknuti portretist, pejzažist (među pretečama plenerizma) i slikar žanr-prizora. Utjecao na hrvatske slikare 19. stoljeća. O Waldmülleru vidjeti: MARIJANA SCHNEIDER (bilj. 14), 38; Enciklopedija hrvatske umjetnosti, sv. 2, Leksikografski zavod »Miroslav Krleža«, Zagreb, 1996., 472; BRUNO GRIMSCHITZ, Ferdinand Georg Waldmüller, Leben und Werk, Wilhelm Andermann Verlag, Wien, 1943.; MARIA BUCHSBAUM, Ferdinand Georg Waldmüller, Rezidenz Verlag, Salzburg, 1967.; KLAUS ALBRECHT SCHRÖDER, Ferdinand Georg Waldmüller, Prestel-Verlag, München, 1990.; RUPERT FEUCHTMÜLLER, Ferdinand Georg Waldmüller, 1793 -1865. Leben-Schriften-Werke, Christian Brandstätter Verlag, WienMünchen, 1996.; AGNES HUSSLEIN-ARCO, SABINE GRABNER, ELISABETH FOUCART-WALTER, ELKE DOPPLER, UDO FELBINGER, ANDREW WILTON, Ferdinand Georg Waldmüller 1793-1865, Skira Flammarion, Musée Du Louvre Éditions, Paris, 2009.

$17 \mathrm{Na}$ ustupljenoj građi i susretljivosti zahvaljujem Narodnoj Galeriji u Ljubljani, ravnateljici dr. Barbari Jaki, višoj kustosici Jassmini Marijan i dr. Andreju Smrekaru, muzejskom savjetniku.

18 GRGO GAMULIN (bilj. 14), 81.

19 ALESSANDRO QUINZI (bilj. 15), 75, 142.

20 RENATA KOMIČ, Stroj in Tominc malo po francosko, Bilten SUZD, 4 (2009.), URL: http://www.suzd.si/bilten/bilten-suzd-2009-4/ raziskave/144-renata-komi-stroj-in-tominc-malo-po-francosko (29. 10. 2015.). Kako navodi R. Komič, po slici Édouarda Louisa Dubufea (Pariz, 1819. - Versailles, 1883.) bila je već 1840 . tiskana grafika, pa su oba slikara, kako Tominc tako i Stroj, mogli preuzeti taj detalj sa slike popularnoga francuskog portretista.

21 ANKA BULAT-SIMIĆ (bilj. 14), 19, 41-42, sl. 19.; KSENIJA ROZMAN (bilj. 14), 20, 49, 78. 
22 ANKA BULAT-SIMIĆ (bilj. 14), 43, sl. 26.

23 ANKA BULAT-SIMIĆ (bilj. 14), 23, 45, sl. 37; KSENIJA ROZMAN (bilj. 14), 21, 50, 87.

24 RUDOLF ANDREJKA, Zgodovina Hudovernikove hiše, Kolodvorska ulica $23 v$ Ljubljani, Kronika slovenskih mest, 7/4 (1940.), 246. Na sljedećoj stranici (247.) reproduciran je i Strojev portret njezina supruga, trgovca Primoža Hudovernika. Iz vrlo loših reprodukcija nije moguće uočiti slikarev potpis i eventualnu dataciju. No, prema prikazanoj dobi, portret Katarine Hudovernik (rođena je 1814.) Stroj je mogao naslikati oko godine 1845. S kotorskim portretom povezuje ga ne samo položaj stilizacija ruku nego i cjelokupni stav portretirane, kao i stereotipnost pojedinih detalja.

25 ANKA BULAT-SIMIĆ (bilj. 14), 52, sl. 81.

26 Fotografija preuzeta s: URL: http://www.liveinternet.ru/community/1726655/post240069756/ (31. 5. 2015.).

27 ALESSANDRO QUINZI (bilj. 15), 67. Ovaj upitni Tominčev portret datiran je oko godine 1838., a tako postavljene ruke koje je poslije često ponavljao, Stroj je prvi put naslikao oko 1835. na portretu žene Aleksandra Vilharja.

28 ALESSANDRO QUINZI (bilj. 15), 232. Iznosi da je portret mogao nastati kao djelo Giovannija Pagliarinija pod Tominčevim utjecajem. Nije suvišno napomenuti da u bogatom dokumentacijskom dijelu Tominčeve monografije A. Quinzija, u kojem se navode ili opisuju nestale i one samo spomenute slike, nema naznaka o portretu Caroline Mazzalors-Hassmann.

29 Slika potječe iz zagrebačkog doma prof. Stjepana Szavits-Nossana, potomka portretirane dame. Na ustupljenoj snimci i podacima zahvaljujem Muzeju za umjetnost i obrt iz Zagreba, posebno gospođi Antoniji Dejanović.

30 ANKA BULAT-SIMIĆ (bilj. 14), sl. 42; KSENIJA ROZMAN (bilj. 14), 93.

31 ALESSANDRO QUINZI (bilj. 15), 133; NADIA BERTONI CREN, Restauro Della Famiglia Sinigaglia di Giuseppe Tominz e analisi della preparazione a bianco di piombo, u: Effetto luce. Materiali, tecnica, conservazione della pittura dell'Ottocento, Atti del convegno IGIIC, 13-14 XI. 2008, Firenze, 2009., 265-274.

32 ALESSANDRO QUINZI (bilj. 15), 91.

33 Dunajski bidermajer, katalog izložbe, Narodna galerija, Ljubljana, 1981., 51, 124.

34 FRANÇOIS BOUCHER, Historie du Costume en occident de lantiquité a nois jours, Flammarion, Paris, 1965., 357.

35 Bidermajer u Hrvatskoj 1815-1848. Arhitektura, urbanizam, skulptura, slikarstvo, umjetnički obrt, književnost, glazba, moda, fotografija, katalog izložbe, Muzej za umjetnost i obrt, Zagreb, 1997., 168.

36 ERIKA THIEL, Geschichte des Kostüms. Die europäische Mode von den Anfängen bis zur Gegenwart, Henschelverlag, Berlin, 1963., 536.

37 FRANÇOIS BOUCHER (bilj. 34), 359.

38 JAMES LAVER, Costume Through the Ages, Thames and Hudson, London, 1963., 89.

39 ANKA BULAT-SIMIĆ (bilj. 14), 49, sl. 58.

40 MARIJANA SCHNEIDER (bilj. 14), 125.

41 MILLIA DAVENPORT, The Book of Costume, vol. II, Crown Publishers, New York, 1948., 866 (fotografija 2475). Čini se da fotografirana dama ima kao dio svoje odjeće i kravatu što bi mogao biti prvi poznati primjer (i to u Škotskoj početkom 1840-ih) dodatka kravate ženskoj odjeći.

42 AKISON GERNSHEIM, Victorian and Edwardian Fashion. A Photographic Survey, Dover Publications Inc., New York, 1981., 42, sl. 16.

43 ERIKA THIEL (bilj. 36), 537.

44 GEORG HIMMELHEBER, Kunst des Biedermeier 1815-1835. Architektur, Malerei, Plastik, Kunsthaudwerk, Musik, Dichtung und Mode, Prestel-Verlag, München, 1988., 172.

45 JIŘI RAK, RADIM VONDRĂČEK, CLAUDIA TERENZI, Biedermeier - Art and Culture in Central Europe 1815 - 1848, Skira, Milano, 2001., 171.
46 BRUNO GRIMSCHITZ (bilj. 16), 58.

47 GÜNTER DÜRIEGL, ROBERT WAISSENBERGER, TINO ERBEN, Bürgersinn und Aufbegehren. Biedermeier und Vormärz in Wien 18151848, Sonderausstellung Historiches Museum der Stadt Wien, Verlag Jugend und Volk, Wien, 1988., 167, 195.

48 Najistaknutiji minijaturist zagrebačkog kruga Jakov Stager djeluje u Zagrebu i drugim gradovima sjeverozapadne Hrvatske između 1840. i 1846. godine, slikajući bidermajerske minijaturne portrete oblikovane plošno, zatvorenom linijom, većinom dvobojnim namazima čiste boje. Usporedi: MARIJANA SCHNEIDER (bilj. 14), 34-35, 62, 73, 80-82, 94, 113, 117-118, 123; GRGO GAMULIN (bilj. 14), 23, 88, 116; Enciklopedija hrvatske umjetnosti, sv. 2, Leksikografski zavod "Miroslav Krleža», Zagreb, 1996., 264-265.

49 Bidermajer u Hrvatskoj 1815-1848. (bilj. 35), 427-428; ANKA BULAT-SIMIĆ, Minijaturisti zagrebačkog kruga (1840-1850), Radovi Instituta za povijest umjetnosti, 1-2 (1972.), 68-93, kat. br. 4, 6 .

50 Muzej za umjetnost i obrt Zagreb: izbor iz fundusa, (ur.) Vladimir Maleković, Centro Affari e Promozioni, Arezzo, 1991., 65, 159.

51 Riječanin Ljudevit Cetinović, nakon bečke Akademije, od 1839. godine djeluje u Ljubljani, a potom od 1842. u Hrvatskoj, slikajući portrete, oltarne slike i krajolike. Usporedi: Enciklopedija hrvatske umjetnosti, sv. 1, Leksikografski zavod »Miroslav Krleža«, Zagreb, 1995., 150; BARBARA JAKI (bilj. 14, 1998.), 10; MARGITA CVIJETINOVIĆ STARAC, Portreti iz fundusa Muzeja: katalog muzejskih zbirki II, Pomorski i povijesni muzej Hrvatskog primorja Rijeka, Rijeka, 1990.

52 Muzej za umjetnost i obrt Zagreb (bilj. 50), 63, 157.

53 Bidermajer u Hrvatskoj 1815-1848. (bilj. 35), 391; Muzej za umjetnost i obrt Zagreb (bilj. 50), 158.

54 MARIJANA SCHNEIDER (bilj. 14), 103. Prema podatku dr. Marine Bregovac Pisk, voditeljice Zbirke slika, grafika i skulptura Hrvatskoga povijesnog muzeja, autor ove slike zabilježen je i kao Anton Hölperl. 55 JIŘI RAK, RADIM VONDRĂČEK, CLAUDIA TERENZI (bilj. 45), 125.

56 KSENIJA ROZMAN (bilj. 14), 12-13 (autorica podatke crpi iz: Mestni arhiv Ljubljana, Reg. I, fasc. 1291/1839).

57 Sačuvao se kod potomaka u Trstu, a dostupan nam je posredstvom nedovoljno kvalitetne fotografije koju mi je ljubazno ustupio gospodin Zoroslav Radimir iz Dobrote.

58 Slikar i fotograf Andrea de Castro iz Pirana djelovao je u Trstu kao slikar portretnih minijatura, a potom od 1855. do 1857. kao slikar-retušer kod tršćanskog fotografa $M$. Stipanicha. Krajem 50 -ih otvorio je $s$ kćeri u Goriziji vlastiti fotografski studio (Nuovo studio Fotografico del pittore A. de Castro e figlia). Radio je i u Rovigou i Udinama, a od 1861. pomaže kćeri Eugeniji (Trst, 1839.-1917.), prvoj tršćanskoj fotografkinji, koja nakon udaje za fotografa Ferdinanda Ramanna nastavlja rad u suprugovu studiju. Usporedi: CLAUDIO H. MARTELLI, Dizionario degli artisti di Trieste, dell'isontino, dell' Istria e della Dalmazia, Hammerle Editore, Trieste, 2009., 122; MASSIMO BERTOLUCCI, MARIAGIULIA BURRESI, "De Castro, Andrea«, Allgemeines Künstlerlexikon: die bildenden Künstler aller Zeiten und Völker, sv. 25, (ur.) Günther Meissner, K. G. Saur Verlag, München-Leipzig, 2000., 101; MARIJANA SCHNEIDER (bilj. 14), 18; LUCIANO SPANGHER, SERGIO TAVANO, Gorizia in posa, Editrice Goriziana, Gorizia, 1989., 189; LAURA RUARO LOSERI, Ritratti a Trieste, Editalia, Roma, 1993., 14, 25. Portretna minijatura s prikazom gospođe Hassmann odaje istu ruku kao potpisan De Castrov Portret žene s punđom iz Zbirke Marton (oko 1830., tempera na bjelokosti, $8,7 \times 7 \mathrm{~cm}$, sign. 1. d.: A de Castro). Znatnu sličnost nalazimo i usporedbom s De Castrovom potpisanom minijaturom Portret mlade žene, datiranom oko 1840. (mrežna stranica Institut du Grenat), a manju s Portretom Anke Stanković iz Hrvatskoga povijesnog muzeja (oko 1830., minijatura na bjelokosti, $6,7 \times 5,7 \mathrm{~cm}$, sign. 1.: Castro). $S$ obzirom na to da na potonjoj ne nalazimo inicijal imena, moguće je da je rad njegova brata, također slikara portretnih minijatura, Luigija de Castra. Usporedi: Kolekcija Marton, katalog izložbe, Muzej za umjetnost i obrt, Zagreb, 2002., 44.; Institut du Grenat, URL: http://www.institutdugrenat.com/2012/11/andrea-de-castro-portrait-de-jeune-femme (29. 10. 2015.); MARIJANA SCHNEIDER (bilj. 14), 111; LAURA RUARO LO- 
SERI (bilj. 58), 29. Da je zaista riječ o De Castrovoj minijaturi potvrđuje nam i zapis iz već citiranog, kasnije pronađenog rukopisa, konta Ivana Smeće s popisom obiteljske imovine (Memorie sopra la famiglia Conti de Smecchia radunate da me Giovanni Conte Smecchia, Trieste 22 Febrajo 1916). Na str. 65, pod inventarnim brojem 38, stoji: »Miniatura sopra avario, lavoro di Castro rappresentante Carolina Mazzalors-Hassmann «. Zabilješka o vlasništvu slike jednaka je kao i za kotorski portret (bilj. 11). 59 Identitet portretirane dame potvrđen je i na poleđini minijature, zapisom: "Carolina Hassmann moglie di Giovanni Mazzalors, genitori di Emilia moglie di Stanislavo Conte de Smecchia«.

60 KSENIJA ROZMAN (bilj. 14), 13.

61 Usporedbu naslikana inkarnata s površinom porculana prva je iznijela Anka Simić-Bulat, vrlo zaslužna istraživačica Strojeva opusa. Usporedi: Slikarstvo XIX stoljeća u Hrvatskoj, katalog izložbe, Galerija slika grada Zagreba »Benko Horvat«, Zagreb, 1961., 24-25.

\section{REFERENCES}

RUDOLF ANDREJKA, Zgodovina Hudovernikove hiše, Kolodvorska ulica $23 v$ Ljubljani, Kronika slovenskih mest, 7/4 (1940), 241-249.

MASSIMO BERTOLUCCI, MARIAGIULIA BURRESI, "De Castro, Andrea", Allgemeines Künstlerlexikon: die bildenden Künstler aller Zeiten und Völker, Vol. 25, (ed.) Günther Meissner, K. G. Saur Verlag, München-Leipzig, 2000, 101.

NADIA BERTONI CREN, Restauro Della Famiglia Sinigaglia di Giuseppe Tominz e analisi della preparazione a bianco di piombo, in: Effetto luce. Materiali, Tecnica, conservazione della pittura dell'Ottocento, Atti del convegno IGIIC, 13-14 XI. 2008, Firenze, 2009, 265-274.

Bidermajer u Hrvatskoj 1815-1848. Arhitektura, urbanizam, skulptura, slikarstvo, umjetnički obrt, književnost, glazba, moda, fotografija, exhibition catalogue, Muzej za umjetnost i obrt, Zagreb, 1997.

FRANÇOIS BOUCHER, Historie du Costume en occident de l'antiquité a nois jours, Flammarion, Paris, 1965.

ŽELJKO BRGULJAN, Zavjetni darovi bokeljskih pomoraca u crkvama Kotorske biskupije, in: Zavjetni darovi bokeljskih pomoraca, exhibiton catalogue, Muzej za umjetnost i obrt, Zagreb, 2014, 13-40.

MARIA BUCHSBAUM, Ferdinand Georg Waldmüller, Rezidenz Verlag, Salzburg, 1967.

ANKA BULAT-SIMIĆ, Mihael Stroy, Društvo historičara umjetnosti Hrvatske, Zagreb, 1967.

ANKA BULAT-SIMIĆ, Minijaturisti zagrebačkog kruga (1840-1850), Radovi Instituta za povijest umjetnosti, 1-2 (1972), 68-93.

MARGITA CVIJETINOVIĆ STARAC, Portreti iz fundusa Muzeja: katalog muzejskih zbirki II, Pomorski i povijesni muzej Hrvatskog primorja Rijeka, Rijeka, 1990.

SLAVKO DABINOVIĆ, Povratak u zavičaj: Pomorski muzej Crne Gore u Kotoru priredio izložbu obiteljskog nasljeđa Nade Radimir, Hrvatski glasnik, 118 (2015), 28-30.

MILLIA DAVENPORT, The Book of Costume, Vol. II, Crown Publishers, New York, 1948.

Dunajski bidermajer, exhibition catalogue, Narodna galerija, Ljubljana, 1981.

GÜNTER DÜRIEGL, ROBERT WAISSENBERGER, TINO ERBEN, Bürgersinn und Aufbegehren. Biedermeier und Vormärz in Wien 1815-1848, Sonderausstellung Historiches Museum der Stadt Wien, Verlag Jugend und Volk, Wien, 1988.

Enciklopedija hrvatske umjetnosti, 2 Vols., Leksikografski zavod "Miroslav Krleža”, Zagreb, 1995-1996.

RUPERT FEUCHTMÜLLER, Ferdinand Georg Waldmüller, 1793-1865. Leben-Schriften-Werke, Christian Brandstätter Verlag, Wien-München, 1996.

GRGO GAMULIN, Mihael Stroy, in: Hrvatsko slikarstvo XIX. stoljeća, Vol. 1, Naklada Naprijed, Zagreb, 1995, 68-82.

Genealogie online, URL: https://www.genealogieonline.nl/en/stamboomrietveld/I5209.php (26/10/15).
AKISON GERNSHEIM, Victorian and Edwardian Fashion. A Photographic Survey, Dover Publications Inc., New York, 1981.

BRUNO GRIMSCHITZ, Ferdinand Georg Waldmüller, Leben und Werk, Wilhelm Andermann Verlag, Wien, 1943.

GEORG HIMMELHEBER, Kunst des Biedermeier 1815-1835. Architektur, Malerei, Plastik, Kunsthaudwerk, Musik, Dichtung und Mode, Prestel-Verlag, München, 1988.

AGNES HUSSLEIN-ARCO, SABINE GRABNER, ELISABETH FOUCART- WALTER, ELKE DOPPLER, UDO FELBINGER, ANDREW WILTON, Ferdinand Georg Waldmüller 1793-1865, Skira Flammarion, Musée Du Louvre Éditions, Paris, 2009.

Institut du Grenat, URL: http://www.institutdugrenat.com/2012/11/andrea-de-castro-portrait-de-jeune-femme (29/10/15).

BARBARA JAKI, Bidermajersko slikarstvo iz zbirki Narodne galerije, Ljubljana, in: Slovensko bidermajersko slikarstvo iz zbirki Narodne galerije, Ljubljana, exhibition catalogue, Muzej za umjetnost i obrt, Zagreb, 1998, 5-13.

BARBARA JAKI, Mihael Stroj, in: Meščanska slika: slikarstvo prve polovice 19. stoletja iz zbirk Narodne galerije, exhibition catalogue, Narodna galerija, Ljubljana, 2000, 210-249.

BARBARA JAKI, Jožef Tominz, in: Meščanska slika: slikarstvo prve polovice 19. stoletja iz zbirk Narodne galerije, exhibition catalogue, Narodna galerija, Ljubljana, 2000, 250-275.

Jožef Tominc, Fiziognomija slike, exhibition catalogue, Narodna galerija, Ljubljana, 2002.

Kolekcija Marton, exhibition catalogue, Muzej za umjetnost i obrt, Zagreb, 2002.

RENATA KOMIČ, Stroj in Tominc malo po francosko, Bilten SUZD, 4 (2009), URL: http://www.suzd.si/bilten/bilten-suzd-2009-4/raziskave/144-renata-komi-stroj-in-tominc-malo-po-francosko (29/10/15).

JAMES LAVER, Costume Through the Ages, Thames and Hudson, London, 1963.

CLAUDIO H. MARTELLI, Dizionario degli artisti di Trieste, dell'isontino, dell' Istria e della Dalmazia, Hammerle Editore, Trieste, 2009.

Muzej za umjetnost i obrt Zagreb: izbor iz fundusa, (ed.) Vladimir Maleković, Centro Affari e Promozioni, Arezzo, 1991.

KRUNO PRIJATELJ, Slike Josipa Tominca u Boki Kotorskoj, in: Studije o umjetninama u Dalmaciji I, Zagreb, 1963, 95-98.

ALESSANDRO QUINZI, Giuseppe Tominz, Fondazione CRTrieste, Trieste, 2011

JIŘI RAK, RADIM VONDRĂČEK, CLAUDIA TERENZI, Biedermeier Art and Culture in Central Europe 1815 - 1848, Skira, Milano, 2001.

KSENIJA ROZMAN, Mihael Stroj 1803-1871, Narodna galerija, Ljubljana, 1971.

LAURA RUARO LOSERI, Ritratti a Trieste, Editalia, Roma, 1993.

MARIJANA SCHNEIDER, Portreti 1800 - 1870., Katalog muzejskih zbirki IX, Povijesni muzej Hrvatske, Zagreb, 1973.

KLAUS ALBRECHT SCHRÖDER, Ferdinand Georg Waldmüller, Prestel-Verlag, München, 1990.

Slikarstvo XIX stoljeća u Hrvatskoj, exhibition catalogue, Galerija slika grada Zagreba "Benko Horvat", Zagreb, 1961.

LUCIANO SPANGHER, SERGIO TAVANO, Gorizia in posa, Editrice Goriziana, Gorizia, 1989.

ERIKA THIEL, Geschichte des Kostüms. Die europäische Mode von den Anfängen bis zur Gegenwart, Henschelverlag, Berlin, 1963.

BORIS VIŽINTIN, Prilog biografijama slovenskih slikara Josipa Tominca, Matije Tomca, Gaspara Götzla i Josefe Štrus, Peristil, II (1957), 205-209.

\section{ARCHIVAL SOURCES}

Memorie sopra la famiglia Conti de Smecchia radunate da me Giovanni Conte Smecchia, Trieste 22 Febrajo 1916, manuscript owned by the Smecchia family heirs 
Summary

\section{Željko Brguljan}

\section{A Proposal for a Contribution to the Oeuvre of Mihael Stroj}

The paper analyses the "Portrait of Carolina Mazzalors-Hassmann", recently donated to the Maritime Museum of Montenegro in Kotor from the estate of the noble Boka family of Smecchia. On the basis of comparison with autograph works from museum and private collections, the author attributes the portrait to the Slovenian painter Mihael Stroj (Ljubno, 1803 - Ljubljana, 1871), motivated by the unique modelling of the face, the grace of the figure and the position of the portrayed lady's stylized hands, carefully and skilfully painted drapery, but also the balance between the figure and other figural elements - the romantic landscape in the distance, and especially the painter's idiomatic treatment of skin which results in characteristically rendered smoothness of porcelain-like surface. All these elements of incontestable quality, despite evident decorative features, encourage the attribution of this unknown but complete work which emanates beauty and wondrousness to precisely this author and his characteristic elegant manner.

On the basis of similar hairstyles and clothes and by comparison with other portraits and surveys of contemporary fashion and biographical details of the portrayed person, the author attempts to determine the year in which the painting was created, concluding that it was executed around 1840. It could have been painted during the life of Mrs Mazzalors-Hassmann, but also after her premature death, after a portrait miniature by Andrea de Castro preserved by the heirs, which displays an identical facial expression and pose of the portrayed lady.

The relocation of the "Portrait of Carolina Mazzalors-Hassmann" from the salon of its previous owners to the permanent collection of the museum in Kotor has prompted an interest among both the public and art professionals, and the proposed attribution to Mihael Stroj is believed to earn the portrait a special place within the oeuvre of this prominent painter of the Viennese circle of the Biedermeier period. 